\title{
The Returns to Attending a Prestigious Law School*
}

\author{
Paul Oyer ${ }^{\dagger}$ and Scott Schaefer
}

September 30, 2010

\begin{abstract}
We measure the returns to attending a highly ranked law school using the "After the JD" survey of lawyers first passing the Bar Exam in 2000. In 2002 and 2007, those lawyers that went to top 10 law schools made, on average, $25 \%$ more than those that went to schools ranked 11-20 and over 50\% more than those that went to schools ranked 21-100. Graduates of Top 10 schools were also much more likely to work in large law firms in leading law markets. We use two methods to assess the degree of selection in the law school prestige premium - the methods developed by Altonji, Elder, and Taber (2005), who focus on the relationship between observable and unobservable variables, and propensity score matching. We find that at least a third of the large returns to law school reputation are due to selection, but this selection is almost entirely on a single variable - quality of the undergraduate institution attended. Selection on other background characteristics is trivial. Whatever unobservables lead to selection into top undergraduate schools may also lead to selection into top law schools. Our results are consistent with a reasonably large causal effect of attending an elite law school, but the exact size of the premium depends varies with assumptions about the role of unobservables.
\end{abstract}

*PRELIMINARY - PLEASE DO NOT QUOTE, CITE, OR DISTRIBUTE. We thank Robert Nelson, Gabriel Plickert, and JeeYoon Park for helping us enhance the AJD dataset, Dan Black and Jeff Smith for the college quality data, David Chambers for analyzing the Michigan Alumni data for us, William Vijverberg for research assistance, Todd Elder for providing programs and technical assistance, and Richard Brooks, Hanming Fang, Dan Ho, Richard Sander, and participants in seminars and conferences for comments.

${ }^{\dagger}$ Stanford University Graduate School of Business and NBER. pauloyer@stanford.edu.

${ }^{\ddagger}$ David Eccles School of Business and Institute for Public and International Affairs, University of Utah. scott.schaefer@utah.edu. 


\section{Introduction}

Graduate students comprise an increasingly large share of overall U.S. higher education attendance. ${ }^{1}$ Despite this, the large economics literature on the returns to education and educational quality has paid relatively little attention to graduate education. One particularly large graduate sector that has grown considerably since 1970 is law school. ${ }^{2}$ While the market for lawyers has grown, competition for admission to top US law schools has become very intense. For example, 7,168 people paid $\$ 75$ each to apply to the Harvard Law School class of 2011 (as well as $\$ 132$ each time they took the Law School Admission Test [LSAT]). Only 11\% were accepted. Aspiring lawyers work very hard to get good grades as undergraduates and take other actions to make their applications more attractive. A substantial fraction of aspiring lawyers invest in LSAT preparation classes and materials that typically cost $\$ 1,000$ or more and require over 50 hours in classroom time alone. ${ }^{3}$

Is it worth it? Does it matter what law school an aspiring lawyer attends? Conventional wisdom suggests that top lawyers come exclusively from top law schools and that entry to a top law school is a ticket to partnership at a top firm. However, there are reasons to question the belief that going to a top law school will make a lawyer successful. First, there are many highly successful lawyers from less prestigious schools. For example, Sullivan \& Cromwell LLP and Skadden, Arps, Slate, Meagher, and Flom LLP rank as the third and fourth most prestigious firms, according to Vault.com. Not surprisingly, both firms have many graduates of Harvard, Yale, Columbia, and other top law schools in their associate and partner ranks. But Sullivan \& Cromwell also has at least two associates and at least two partners from each of Brooklyn, Catholic, and Ohio State Law Schools. Skadden has, for example, ten associates and three partners from Villanova, eight associates and three partners from the University of Connecticut, and eight associates and nine

\footnotetext{
${ }^{1}$ The National Center for Education Statistics publishes tables on the U.S. Department of Education website indicating that full time undergraduate attendance grew by $58 \%$ between 1976 and 2006 and is expected to grow $12 \%$ from 2006 to 2017. Full time graduate school attendance grew by $103 \%$ from 1976 to 2006 and is expected to grow by $20 \%$ from 2006 to 2017 .

${ }^{2}$ Lawyer growth was particularly intense in the 1970's when the lawyer population increased by $90 \%$ and from 1980 to 1988 when it increased 48\% (see Sander and Williams (1989) and Figure 1 in Rosen (1992)). In 1996, lawyers made up approximately $5 \%$ of all graduate students. We have not been able to find more recent growth statistics. It appears that the largest firms have continued to grow substantially while the number of lawyers entering the market (at least from elite schools) has leveled off. For example, Stanford Law School's class of 2005 had 166 graduates. This is similar to the class of 1980 (164) but much larger than the class of 1970. Similarly, University of Utah's classes of 2005, 1980, and 1970 were 140,133, and 92, respectively. Some schools have continued to grow since 1980 , but Stanford and Utah are quite typical.

${ }^{3}$ A 1989 study of law school applicants (Wightman (1990)) found that about half took an LSAT preparation class. We suspect this number has, if anything, grown since the time of that study. Current LSAT preparation offerings from Kaplan, an industry leader, include classes that range in price from $\$ 1,300$ to $\$ 1,500$ and involve 51 to 109 classroom hours. The company also offers an intensive summer course with $300+$ hours in class at a cost of $\$ 8,000$ and private training packages ranging from $\$ 2,300$ to $\$ 4,500$. A Kaplan online self-study class costs $\$ 1,150$.
} 
partners from St. Johns. ${ }^{4}$

Apart from these examples of very successful lawyers from less prestigious schools, the fact that the most prestigious law schools are able to attract candidates with the most impressive backgrounds suggests that a large part of the association between law school prestige and lawyer success could be due to selection effects. As we will discuss, there is a large literature indicating that much of the relationship between undergraduate school selectivity and labor market outcomes is due to better schools attracting more talented students. The causal effect of undergraduate school prestige on wages is not generally considered to be large. The selection component of the school ranking/wage relationship might be particularly important for lawyers relative to undergraduates and other graduate students, leading to a small causal effect of school prestige on labor market outcomes, because prospective employers have relatively good information about law students. Law school grades are generally disclosed (unlike at many business schools, for example) and other honors, such as Order of the Coif and law review positions, are publicized. This may make it easier for employers to identify student ability levels independent of what school they attend.

In this paper, we use a large, representative dataset of lawyers that first passed the bar in 2000 to measure the relationship between law school prestige and lawyers' success in the labor market. We first show that law school prestige is, on average, associated with a large wage premium and a much higher probability of holding a "prestigious" position (which we define as working at a firm with 100 or more lawyers in one of the top four geographic law markets.) Graduates of a top 10 law school (using U.S. News and World Report rankings) earn an average of $25 \%$ more than graduates of schools ranked between eleven and twenty and over $50 \%$ more than graduates of top 100 schools not in the top 20. This prestige premium is similar for lawyers two years after they pass the bar exam and seven years after they pass the bar. We then spend the rest of the paper taking various approaches to separate the portion of the wage premium that is due to selection from the causal effect of going to a top school. While we find that selection into top schools is associated with demographic and background variables that may independently affect a lawyers' success, we find relatively little evidence that these characteristics drive the school selectivity premium. However, we find that the prestige of the undergraduate institution attended can account for a significant portion of the law school prestige premium (at least a third), suggesting that whatever unobservables drive selection into top colleges also drive selection into top law schools. Using the methods in Altonji, Elder, and Taber (2005) and propensity score matching, we find further evidence of the potential importance of selection on unobservables. For comparison, we perform similar analyses of the effect

\footnotetext{
${ }^{4}$ The Sullivan \& Cromwell and Skadden lawyer information comes from the firms' web pages and is based on the data used in Oyer and Schaefer (2010a).
} 
of undergraduate school prestige using the National Longitudinal Survey of Youth. We find that the law school prestige effects on labor market outcomes are larger and more robust to inclusion of demographic variables than similar effects for undergraduate institution prestige.

These results are consistent with law school prestige affecting lawyer pay in up to three ways top undergraduate schools and top law schools providing lawyers with access to high value networks, top schools (both undergraduate and law schools) doing a relatively good job of teaching some skill that is valuable to lawyers, or top law schools and top undergraduate schools both being able to select the most talented potential lawyers using information that is unobservable to us. Overall, we believe the evidence is consistent with there being a substantial causal effect of attending a top law school, especially for lawyers that did not attend a top undergraduate institution, and that investments by a marginal candidate in obtaining admission to a top school are likely to be good ex ante investments. However, these conclusions rely, to some degree, on the assumptions one is willing to make about unobservables.

Despite the large literature on the effects of college quality measures on earnings, we do not know of any prior study of the effects of law school reputation on earnings. ${ }^{5}$ Given that the number of people going to law school or other graduate schools has increased substantially in recent years, it seems worthwhile to understand how the prestige of these schools relates to labor market outcomes. In fact, the prestige effects of law and other trade schools may be of more interest to education consumers and policy makers than the returns to college quality measures because the primary goal of professional schools is to advance their students' careers. If there is little or no financial return to going to Harvard instead of University of Massachusetts as an undergraduate, one may still justify attending Harvard based on the non-pecuniary value of an elite liberal arts education. While there are similar non-pecuniary advantages of attending law school at Harvard instead of University of Massachusetts, we would expect these to be a less important consideration.

Our paper is related to several other literatures in labor economics, the economics of education, and studies of the legal profession. We discuss the relevance of prior studies on the effects of undergraduate school quality in detail in the next section. See Galanter and Palay (1991) and Galanter and Henderson (2008) for background on the traditional partner track at large and prestigious law firms. Ehrenberg (1989) looks at the relationship between pay and law school prestige, but his analysis is at the school level and makes no attempt to separate selection and value-added. Spurr (1987) shows that lawyers from better law schools work for more prestigious firms, on average, and

\footnotetext{
${ }^{5}$ The papers by Sander (2004) and Arcidiacono, Cooley, and Hussey (2008) that we discuss below are the only papers we know of that relate labor market success to the reputation of any type of graduate school. Neither of those papers focuses on the effect of going to programs of varying reputation, however.
} 
handle legal issues with greater stakes. Rosen (1992) describes many facets of the lawyer labor market, including determinants of pay, variation in pay, and growth in the overall market. Henderson and Morriss (2006) analyze law schools' attempts to appear prestigious and how students respond to these in terms of attendance choices.

We are aware of two other papers that relate labor market outcomes to graduate school quality. In one of these, Arcidiacono, Cooley, and Hussey (2008) study the effects of getting an MBA on wages. In specifications similar to ours, they find a large premium (20-25\%) for going to a Top 25 MBA program relative to other schools but a very small difference between Top 10 and Top 11-25 schools. The premiums that they find for Top 25 programs are cut roughly in half when they control for individual fixed effects using pre-MBA salary. We cannot use a similar strategy because we do not have pre-law salary data for our sample and because, unlike MBAs, many lawyers have limited or no work experience before law school. Most of our sample went straight from undergraduate school to law school or waited just one year in between.

The other paper that relates graduate school quality to labor market success is the highly provocative and controversial study of affirmative action "mismatch" by Sander (2004). In fact, Sander (2004) uses the same dataset that we use and he runs regressions similar to those we run. He also finds a substantial premium to attending a top law school, controlling for other factors. However, this is not the focus of his analysis and he does not attempt to determine the causal effect of law school quality on career success. He controls for several variables in his analysis that would be inappropriate to include as explanatory variables in our analysis (such as the geographic area where the lawyer works and the average LSAT of the law school) and he does not explicitly consider the selection vs. value-added issue that we focus on.

In the next section, we provide background on the challenge in measuring the effect of going to a highly ranked school on labor market outcomes and how contributors to the literature on the returns to college selectivity have dealt with this. Section 3 describes the data we use and then shows our empirical analysis using standard regression methods that control for as many indicators of unobserved skill as we can. We attempt to assess the importance of unobserved variables by measuring the degree to which observed and unobserved variables would have to interact if there were no causal effect of law school reputation on labor market outcomes in Section 4 and by using propensity score matching methods in Section 5. We interpret the implications of our results for aspiring lawyers and speculate on possible sources of the law school prestige premium in Section 6 . Section 7 concludes. 


\section{Background on Returns to Selective Schools}

As has been widely studied in the undergraduate context (see below for details), measuring the causal effect of school reputation on labor market outcomes is difficult when unobservable factors such as intelligence and parental investments affect both the school someone attends and her eventual productivity in the workplace. Suppose that person $i$ 's productivity (and, in equilibrium, her pay) is

$$
y_{i}=\alpha_{i}+\beta_{1} x_{i}+\beta_{2} c_{i}+\varepsilon_{i}
$$

where $y$ is output or pay, $x$ is a set of control variables such as age and family background, $c$ is a measure of the reputation of the school she attended, $\alpha$ is person-specific ability, and $\varepsilon$ is a random shock to productivity or to the measurement of productivity. If $c$ were determined randomly conditional on $x$, traditional wage regressions would provide unbiased estimates of $\beta_{2}$, the causal effect of college reputation on income. However, a more reasonable model would suggest that

$$
c_{i}=\theta_{i}+\gamma_{1} x_{i}+\gamma_{2} z_{i}+\eta_{i}
$$

That is, the college the person chooses is likely to be a function of her taste for particular types of schools $(\theta)$, the characteristics that affect her productivity $(x)$, and other characteristics that are observed by school admission officers but not by employers $(z)$. The fact that the college choice is determined endogenously would not cause any problems in interpreting wage regressions using the specification in equation (1) if $\alpha$ were independent of $c$, controlling for the variables in the vector $x$. This condition seems unlikely to be satisfied, though. For example, if person $i$ has a positive work ethic, this is likely to affect productivity through $\alpha$ and make the person's school admission application more attractive through $z$. In this case, a wage regression that did not have individual fixed effects would attribute some of the effects of $\alpha$ to $c$ through an upwardly biased $\beta_{2}$.

Table 1 summarizes several papers that, in the context of undergraduate institution prestige, have taken different approaches to solving the selection issue. That is, different researchers have chosen different methods to get an unbiased estimate of $\beta_{2}$. Behrman, Rosenzweig, and Taubman (1996), who look only at female twins born in Minnesota between 1936 and 1955, use the common background of twins to separate innate ability from the effects of schooling. They find that, at least for this group, there is a substantial wage premium associated with attending an undergraduate school that grants PhDs, small private colleges, and higher faculty salaries. The magnitude of their estimates is quite large, as they suggest that if a given person receives her undergraduate degree from Wellesley College or the University of Pennsylvania instead of Mankato State University in 


\begin{tabular}{|c|c|c|}
\hline Paper & Comparison & Result \\
\hline $\begin{array}{l}\text { Behrman, Rosenzweig, and } \\
\text { Taubman (1996) }\end{array}$ & Female twin pairs. & $\begin{array}{l}\text { Attending Private and PhD- } \\
\text { granting universities leads to } \\
10-25 \% \text { higher earnings. }\end{array}$ \\
\hline $\begin{array}{l}\text { Brewer, Eide, and Ehren- } \\
\text { berg (1999) }\end{array}$ & Model college selection. & $\begin{array}{l}\text { Attending elite schools increase } \\
\text { earnings up to } 40 \% \text { relative to low- } \\
\text { ranked public schools. }\end{array}$ \\
\hline Dale and Krueger (2002) & $\begin{array}{l}\text { Uses students admitted to } \\
\text { same schools but attending } \\
\text { different ones. }\end{array}$ & $\begin{array}{l}\text { Little or no effect of school SAT } \\
\text { scores, but higher tuition leads to } \\
\text { higher earnings. }\end{array}$ \\
\hline Black and Smith (2004) & Propensity score matching. & $\begin{array}{l}\text { Attending a top quartile school in- } \\
\text { creases earnings by up to } 15 \% \text { rela- } \\
\text { tive to a bottom quartile school. }\end{array}$ \\
\hline Hoekstra (2009) & $\begin{array}{l}\text { RDD between state university } \\
\text { campuses. }\end{array}$ & $\begin{array}{l}\text { Those attending campus with }+75 \\
\text { SAT points earn } 20 \% \text { more. }\end{array}$ \\
\hline
\end{tabular}

Table 1: Previous Findings on the Returns to Attending a Selective College

Minnesota, she can expect approximately a $20 \%$ or $36 \%$ wage premium, respectively. Brewer, Eide, and Ehrenberg (1999) use a more representative sample and take a more structural approach by specifying a model for selection of college and subsequent earnings. They identify the causal effect of college quality on wages by instrumenting for college choice through the costs of the school attended and through the functional form of the school choice and wage equations. They find results generally in line with those in Behrman, Rosenzweig, and Taubman (1996). However, the results in Brewer, Eide, and Ehrenberg (1999) are somewhat problematic because, unlike other research in this area and counter to most researchers' intuition, they find that selection correction is not important in measuring the effect of college quality.

Dale and Krueger (2002) and Black and Smith (2004) find much smaller effects of college reputation on earnings. Dale and Krueger (2002) identify the effects of college reputation by comparing earnings of people that were accepted to similar colleges but made different choices about which one to attend. They find essentially no effect of college prestige on earnings. Black and Smith (2004) use propensity score matching techniques to control for school selection. They find that, in most specifications and most subgroups, selection is important. Their estimated causal wage premiums are generally not large, with a maximum of about $15 \%$ for a student that attends a top quartile school relative to if she attended a bottom quartile school. Finally, Hoekstra (2009) uses a regression discontinuity approach by comparing students near the margin for getting into 
the top state university campus in the state. He finds that getting into this campus, where the average SAT score is 65-90 points higher than the other campuses, leads to a zero to twenty percent increase in earnings at ages $28-33 .{ }^{6}$

The variety in the estimated effects of college quality suggests that this effect can be quite heterogeneous and/or that it is difficult to specify the proper selection correction to separate the selection and value-added effects of school quality measures on earnings. But we generally read the results as suggesting that selection is an important component in the correlation between undergraduate school quality and labor market outcomes and think the estimates of the causal effect of college quality are generally small on the margins that most students consider. We suspect that few students that attend Wellesley College seriously consider Mankato State University, for example, or that many students that end up at top schools were ever seriously at risk for attending a school in the bottom quartile.

Below, we produce our own (fairly small) estimates of the causal effect of undergraduate college quality on earnings. But the real innovation in our work is to look at the effect of law school quality so our undergraduate estimates are primarily for comparison and the details are relegated to appendix tables.

\section{$3 \quad$ Data and Simple Regressions}

\subsection{Data}

Our lawyer data comes from the first two waves of the "After the JD" survey, conducted in May 2002 and 2007. The surveys were conducted primarily by mail and phone (with a few responses done over the internet) and had a $70 \%$ response rate. We only used responses from the mail and internet surveys, however, as the phone survey did not gather the background characteristics that are critical to our analysis. We dropped people that were 40 or older when they first passed the bar and anyone who failed to report her law school, age, gender, whether her mother was born in the United States, how she paid for law school, and whether she lived near her mother at the time of the survey. We also limit our analysis to graduates of top 100 law schools (defined below) because we believe the market for lawyers from schools ranked lower that is simply a different market than the market for graduates of the most prestigious schools. Also, the AJD sample imposes some potential selection bias into our analysis because it only included law graduates that pass a bar

\footnotetext{
${ }^{6}$ Studying Colombian students and workers, Saavedra (2008) also uses a regression discontinuity approach. He finds the highest returns to college quality that we know of, indicating the returns may be higher outside the United States.
} 
exam. This problem will be less severe because we drop graduates of lower ranked and unaccredited law schools. Our wage regressions are limited to the 1,425 Wave 1 and 1,646 Wave 2 respondents for whom we have fairly complete data. The sample size is slightly larger $(1,531)$ when we run probits on whether the person works at a large firm in a major legal market because some people provided detail on the type of job they hold but not on their incomes. We can only run these probits for Wave 1 because we do not yet have geographic information for the Wave 2 sample.

We measure the quality, prestige, and selectivity of the lawyers' law school and undergraduate school using US News and World Report rankings. The AJD data provide the 2003 rankings of law schools in six categories varying from Top 10 to Unaccredited. We only use the top three categories - Top 10, other Top 20, and other Top 100. For undergraduate schools, we use twentyfour categories based on the US News 1996 rankings as 1996 is the modal undergraduate completion year for the AJD sample. We created an indicator variable, "Top Undergraduate", which equals one for lawyers whose undergraduate institution ranks as one of the top 25 National Universities or top 25 Liberal Arts Colleges. ${ }^{7}$

Panel A of Table 2 provides details on the Wave 1 sample, as well as for those 201 respondents that went to law schools defined as being in the Top 10 by US News and World Report in 2003 and the 270 who went to other Top 20 schools. $^{8}$ The sample as a whole and each subgroup splits roughly evenly between men and women and averages about thirty years old. Those attending top schools appear to come from somewhat more privileged backgrounds, as their friends and family paid for a higher fraction of their law school expenses and they are more likely to have mothers that continued their education after high school. Those attending more selective schools are, not surprisingly, more likely to have had undergraduate grade point averages above 3.5 and much more likely to have graduated from an elite undergraduate institution. Panel B provides similar information for Wave 2 respondents. They are older at the time of the survey, of course, and they make more money on average. We do not have information on Wave 2 undergraduate GPA and the second wave survey asked about total debt rather than the source of funds for law school, but the two waves look similar and the differences across the law school tiers are consistent for the two waves.

\footnotetext{
${ }^{7}$ We also created an alternative categorization of undergraduate school quality based on average SAT or ACT scores. This led to similar results to those with the US News variable and including both quality measures did not add additional explanatory power. So we use the US News variable throughout the paper.

${ }^{8}$ Because of a tie for number ten, the Top 10 includes the following 11 schools (in order of rank): Yale, Stanford, Harvard, Columbia, NYU, Chicago, Pennsylvania and Michigan (tied), Virginia, and Cornell and Berkeley (tied). "Top 11-20" throughout the paper includes the following schools (ranked 12-20): Duke and Northwestern (tied), Georgetown, Texas, UCLA, Vanderbilt, USC, and Minnesota and Washington and Lee (tied).
} 


\begin{tabular}{|c|c|c|c|}
\hline \multicolumn{4}{|c|}{ Panel A: AJD Lawyers in 2002 (Wave 1) } \\
\hline & All & Top 10 Law School & 11-20 Law School \\
\hline Female & 0.4996 & 0.5174 & 0.51111 \\
\hline \multirow[t]{2}{*}{ Age } & 31.183 & 29.542 & 29.719 \\
\hline & $(3.336)$ & $(2.789)$ & $(2.960)$ \\
\hline \multirow[t]{2}{*}{$\%$ from Fam/Friends } & 0.183 & 0.270 & 0.183 \\
\hline & $(0.305)$ & $(0.365)$ & $(0.305)$ \\
\hline Mother $>$ HS Educ & 0.7614 & 0.8259 & 0.8000 \\
\hline Live near Mother & 0.3579 & 0.3184 & 0.3630 \\
\hline Undergrad GPA $>3.5$ & 0.5193 & 0.8101 & 0.5630 \\
\hline Top Undergrad & 0.2400 & 0.5771 & 0.3074 \\
\hline \multirow[t]{2}{*}{ Annual Pay } & $\$ 88.4 \mathrm{~K}$ & $\$ 122.9 \mathrm{~K}$ & $\$ 98.4 \mathrm{~K}$ \\
\hline & $(46.2 \mathrm{~K})$ & $(44.0 \mathrm{~K})$ & $(43.6 \mathrm{~K})$ \\
\hline Large Firm/Big Mkt & 0.1818 & 0.4577 & 0.2704 \\
\hline $\mathrm{N}$ & 1,531 & 201 & 270 \\
\hline \multicolumn{4}{|c|}{ Panel B: Lawyers in 2007 (Wave 2) } \\
\hline & All & Top 10 Law School & 11-20 Law School \\
\hline Female & 0.4708 & 0.4419 & 0.4831 \\
\hline \multirow[t]{2}{*}{ Age } & 35.072 & 34.577 & 34.704 \\
\hline & $(3.268)$ & $(2.606)$ & $(2.944)$ \\
\hline \multirow[t]{2}{*}{ Debt at L.S. Graduation } & $\$ 65.2 \mathrm{~K}$ & $\$ 76.8 \mathrm{~K}$ & $\$ 66.6 \mathrm{~K}$ \\
\hline & $(40.5 \mathrm{~K})$ & $(47.2 \mathrm{~K})$ & $(39.9 \mathrm{~K})$ \\
\hline Mother $>$ HS Educ & 0.7526 & 0.7778 & 0.7572 \\
\hline Live near Mother & 0.3663 & 0.3140 & 0.3345 \\
\hline Top Undergrad & 0.2503 & 0.5543 & 0.2939 \\
\hline \multirow[t]{2}{*}{ Annual Pay } & $\$ 110.6 \mathrm{~K}$ & $\$ 137.8 \mathrm{~K}$ & $\$ 116.1 \mathrm{~K}$ \\
\hline & $(55.7 \mathrm{~K})$ & $(61.6 \mathrm{~K})$ & $(58.5 \mathrm{~K})$ \\
\hline $\mathrm{N}$ & 1,646 & 258 & 296 \\
\hline
\end{tabular}

Table 2: Summary Statistics 
Our analysis below will focus on two dependent variables. The first of these is the log of the person's annual earnings and the second is an indicator variable that takes the value one if the person works at a private law firm with more than 100 lawyers and in one of the top four legal markets (New York, Washington DC, Chicago, and Los Angeles). The pay differences suggest that those going to Top 10 schools earn more than $40 \%$ more than the sample as a whole and $25 \%$ more than those going to Top 11-20 schools. Figure 1, which displays kernel density estimates of Wave 1 pay differences between Top 10, Top 11-20, and Top 21-100 graduates, provides more detail on pay differences across law school tiers. The graph shows the well-known bi-modal nature of young lawyer earnings (see discussion of this on www.abovethelaw.com and www.elsblog.org) and large differences in what fraction are near the upper mode by law school tier. Figure 2 shows the same graph for Wave 2. Seven years after passing the bar, the distribution of income is no longer bi-modal but the differences across law school quality are similar to those for the earlier wave.

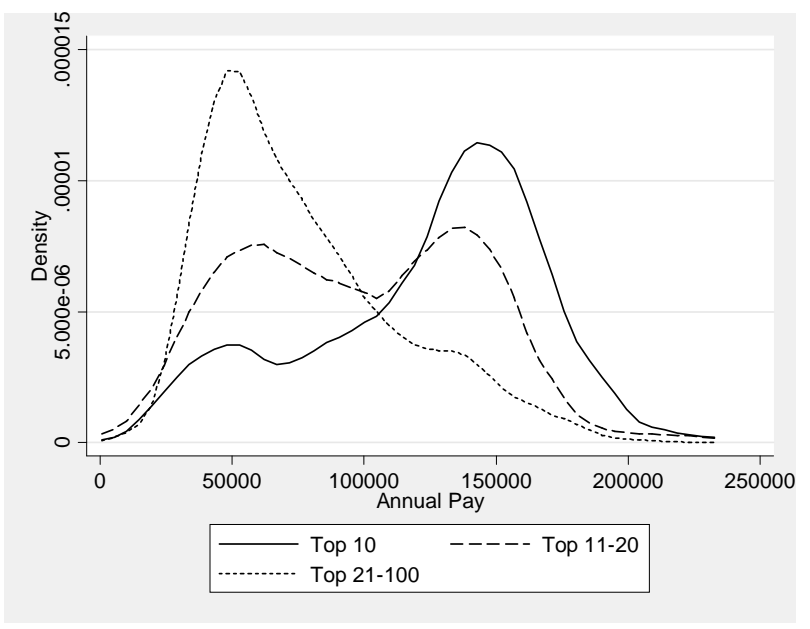

Figure 1: Pay by Law School Tier - Wave 1, 2002

Panel A of Table 2 also shows that Top 10 graduates are much more likely to work for a large law firm in a top law market. These raw differences in pay, type of job, GPA, and background make two things clear - those who go to more selective schools are more successful and had advantages of various kinds even before law school that could be affecting these post-law-school outcomes. The rest of the paper attempts to give a sense for how much of the raw differences in pay and type of job shown in Table 2 are due to selection of the most promising lawyers by the best schools and how much is caused by the law schools people attend.

For comparison purposes, we gathered data on earnings and undergraduate school quality from two sources. We present results using the 1990 wave of the National Longitudinal Survey of Youth (NLSY). We divided the colleges attended into quintiles such that the top and second group are 


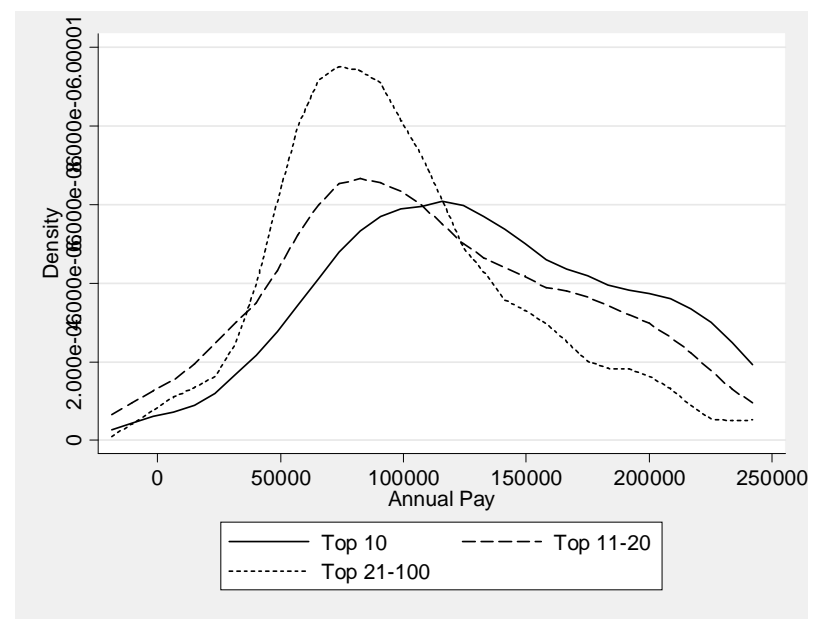

Figure 2: 2006 Pay by Law School Tier - AJD, Wave 2

similar proportions of the NLSY sample as the Top 10 and Top 20 groups are of the AJD sample. We also performed analyses using the Baccaleureate and Beyond (B\&B) survey. This survey has both advantages and disadvantages relative to the NLSY for our purposes and all our analysis led to similar conclusions to those we draw using the NLSY. More detail on both the NLSY and $\mathrm{B} \& \mathrm{~B}$ can be found in the appendix, which is also where we present details of our NLSY analysis. In the main body of the paper, we briefly discuss how the NLSY results compare to the AJD results, as well as the implications of those comparisons. Appendix Table 1 displays summary information for the NLSY comparable to the AJD summary in Table 2. As with the lawyers, the NLSY respondents from better schools come from families with more education and they are more likely to live somewhere different from where they grew up. Again, those going to better schools both make more after school and show more skill before school (as measured by SAT scores), so it is not entirely clear whether the school quality/wage correlation is due to selection or a causal effect of school quality on earnings.

Table 3 explores the potential importance of selection through analyses where measures of school quality are the dependent variables. Panels A and B display results for Waves 1 and 2, respectively. The first two columns of each panel show the results of probits where the dependent variable equals one if the person went to a Top 10 law school. Column 1 uses the whole Top 100 law schools sample while Column 2 is limited to lawyers from Top 20 schools. The results show that selection is likely to be very important. For example, lawyers with at least one parent that graduated from college have a 3 percentage point higher probability of going to a Top 10 school when looking at the whole sample (column 1). Having an undergraduate GPA above 3.5 also has a highly significant (statistically and economically) effect on whether the person attends a Top 10 
law school. Most dramatically, graduating from an elite undergraduate institution is associated with at least a 27 percentage point higher probability of attending a top law school. The third column shows a regression where the dependent variable is 1 if the person went to a US News Top 100 school, 2 if she went to a Top 20 school, and 3 if she went to a Top 10 school. Having a parent that graduated from college is associated with going to a law school that is 0.1 levels higher on this scale and graduating from an elite undergraduate school is associated with more than half a level higher law school. Holding other factors constant, minorities attend higher ranked schools, which could be the result of affirmative action. Reassuringly, given that all the variables in the table do not change once the person goes to law school, the Panel B results for Wave 2 are very similar. The table highlights the potential importance of selection into a top law school and points out the particularly important role of undergraduate institutions. When we run regressions similar to those in Table 3 without controlling for undergraduate school, the coefficients and significance on the other background variables increase substantially indicating (not surprisingly) that the same factors affect selection into undergraduate and law schools.

Appendix table 2 shows similar analyses for undergraduate schools using the NLSY sample. Going to a better undergraduate school is strongly associated with such factors as mother's education, high school rank, and SAT scores. This initial look at who attends top undergraduate and law schools indicates that the potential selection problems are similar in these two distinct environments.

\subsection{OLS Regressions of Income}

We begin by estimating equation (1) for the lawyers in the Wave 1 AJD sample who attended a top 100 school. This includes 1,425 that first passed the bar exam in 2000 and that were under 40 years old at the time. The dependent variable is the log of the lawyer's salary in $2002 .{ }^{9}$ It is common to use the log of a person's hourly wage as the dependent variable in wage regressions such as these, but about a fifth of AJD respondents did not provide hours. Our results are similar, but a bit less precise, if we use hourly wages. Regression results are reported in the first four columns of Table 4.

Column 1 reports results with no control variables, so it provides an indication of the average differences in lawyer pay across six levels of US News and World Report school rankings. The omitted category in each regression is schools in the Top 10, so the other ranks are relative to this top group. Column 1 makes it clear that there are very substantial differences in pay based on where lawyers went to school. Lawyers in schools ranked 11-20 earn approximately $25 \%$ less, on

\footnotetext{
${ }^{9}$ The question in the AJD survey is "What is your total annual salary (before taxes) including estimated bonus, if applicable, at your current job?"
} 


\begin{tabular}{|c|c|c|c|}
\hline \multicolumn{4}{|c|}{ Panel A: AJD Lawyers in 2002} \\
\hline & Top 10 Probit & Top 10 Probit & OLS: US News category \\
\hline \multirow[t]{2}{*}{ Female } & -0.020 & -0.057 & 0.051 \\
\hline & $(0.014)$ & $(0.048)$ & $(0.033)$ \\
\hline \multirow[t]{2}{*}{ Minority } & 0.063 & 0.110 & -0.162 \\
\hline & $(0.018)$ & $(0.051)$ & $(0.036)$ \\
\hline \multirow[t]{2}{*}{ Parent with College Degree } & 0.032 & 0.062 & -0.100 \\
\hline & $(0.015)$ & $(0.059)$ & $(0.038)$ \\
\hline \multirow[t]{2}{*}{ Undergrad GPA $>3.5$} & 0.184 & 0.351 & -0.424 \\
\hline & $(0.016)$ & $(0.044)$ & $(0.033)$ \\
\hline \multirow{2}{*}{$\begin{array}{l}\text { Undergrad Science/Business } \\
\text { Major }\end{array}$} & 0.007 & 0.052 & 0.012 \\
\hline & $(0.014)$ & $(0.048)$ & $(0.033)$ \\
\hline \multirow[t]{2}{*}{ Top Undergrad } & 0.277 & 0.332 & -0.607 \\
\hline & $(0.027)$ & $(0.046)$ & $(0.039)$ \\
\hline $\mathrm{N}$ & 1,531 & 497 & 1,531 \\
\hline \multicolumn{4}{|c|}{ Panel B: AJD Lawyers in 2007} \\
\hline & Top Tier Probit & Top Tier Probit & OLS: Tier \\
\hline \multirow[t]{2}{*}{ Female } & -0.027 & -0.060 & -0.096 \\
\hline & $(0.017)$ & $(0.044)$ & $(0.035)$ \\
\hline \multirow[t]{2}{*}{ Minority } & 0.038 & 0.046 & -0.096 \\
\hline & $(0.019)$ & $(0.046)$ & $(0.038)$ \\
\hline \multirow[t]{2}{*}{ Parent with College Degree } & 0.012 & 0.004 & -0.033 \\
\hline & $(0.018)$ & $(0.045)$ & $(0.036)$ \\
\hline \multirow{2}{*}{$\begin{array}{l}\text { Undergrad Science/Business } \\
\text { Major }\end{array}$} & 0.016 & 0.024 & -0.030 \\
\hline & $(0.018)$ & $(0.045)$ & $(0.036)$ \\
\hline \multirow[t]{2}{*}{ Top Undergrad } & 0.249 & 0.268 & -0.540 \\
\hline & $(0.025)$ & $(0.042)$ & $(0.041)$ \\
\hline $\mathrm{N}$ & 1,646 & 554 & 1,646 \\
\hline
\end{tabular}

Table 3: Selection into Top Schools. Panel A uses first wave of AJD and Panel B uses second wave of AJD. Columns 1 and 2 are probits where the dependent variable is an indicator variable for graduating from a Top 10 law school. The sample in column 2 is limited to those who went to Top 20 schools. Column 3 shows results from an OLS regression where the dependent variable is 1 if the person went to a top 10 school, 2 if he/she went to a school ranked 11-20, and 3 if he/she went to a school ranked 21-100. Coefficients displayed in logits are marginal effect of a one unit change in the explanatory variable. 


\begin{tabular}{lccccc}
\hline & $(1)$ & $(2)$ & $(3)$ & $(4)$ & $(5)$ \\
\hline Rank 11-20 & -0.250 & -0.255 & -0.241 & -0.158 & -0.162 \\
Rank 21-100 & $(0.046)$ & $(0.045)$ & $(0.046)$ & $(0.049)$ & $(0.055)$ \\
& -0.477 & -0.483 & -0.468 & -0.331 & -0.217 \\
Female & $(0.038)$ & $(0.038)$ & $(0.039)$ & $(0.046)$ & $(0.048)$ \\
& & -0.115 & -0.118 & -0.117 & -0.288 \\
Near Mother & & $(0.027)$ & $(0.027)$ & $(0.028)$ & $(0.032)$ \\
& & & -0.034 & -0.027 & 0.002 \\
Undergrad Top 10\% & & & $(0.027)$ & $(0.028)$ & $(0.033)$ \\
& & & & 0.083 & \\
Controls & & & & $(0.042)$ & \\
$\quad$ Demographic & no & yes & yes & yes & yes \\
Family Background & no & no & yes & yes & yes \\
School Funding & no & no & yes & yes & yes \\
Academic History & no & no & no & yes & yes \\
AJD Sample & wave 1 & wave 1 & wave 1 & wave 1 & wave 2 \\
& & & & & \\
R-square & 0.110 & 0.132 & 0.146 & 0.287 & 0.1145 \\
N & 1,425 & 1,425 & 1,425 & 1,425 & 1,646 \\
\hline
\end{tabular}

Table 4: Lawyer Pay Regressions. OLS - Dependent Variable is Log of annual pay. Sample for columns 1-4 is cross-sectional AJD sample in 2002 of lawyers who first passed Bar Exam in 2000. "Rank 11-20" and "Rank 21-100" are based on 2003 US News and World Report rankings. The excluded category is schools ranked in the Top 10. "Near Mother" is an indicator variable for living within 50 miles of respondent's mother. "Undergrad Top 10\%" is a self-reported indicator variable of whether the person was in the top decile of her undergraduate class. Column 5 is similar to column 4, except the sample is the second wave of the AJD. 
average than those in Top 10 schools. Those in schools ranked 21-100 earn another 25\% or so less. Lawyers from Top 10 schools average pay of almost $\$ 123 \mathrm{~K}$, while those from Top 11-20 schools earn about \$98K. Lawyers at "Tier 4" schools (for example, North Carolina Central University, Ohio Northern University, Texas Wesleyan University, and Whittier Law School) earn an average of about $\$ 63 \mathrm{~K}$. We know, therefore, that there is a large wage premium associated with going to a higher ranked law school. The goal for the rest of the paper is to decompose this premium into a part attributable to observable characteristics, part due to unobservable characteristics that people have before attending law school, and a causal effect provided by attending a top school.

Column 2 adds controls for gender, marital status, age (indicators for 25-29, 30-34, etc.), and race (indicators for Black, Hispanic, Native American, Asian, and Other). Some of these control variables are important and they add considerable explanatory power to the regression, as measured by the r-square. Women in the sample earn approximately $12 \%$ less than men (though this difference disappears when we look at hourly pay.) However, adding these controls does not have any effect on the relationship between law school rank and pay.

The specification in column 3 adds several controls for family background and the way the lawyer paid for law school, including whether the lawyer lives near her mother, whether her mother was born in the United States, mother's education, father's education, whether any of her parents or grandparents are lawyers, and the fraction of law school expenses paid through savings and by parents. These variables add some explanatory power and some are significant predictors of lawyer income. However, once again the additional controls have no effect on the law school prestige relationship with pay.

Finally, column 4 includes our fullest set of controls where we try to capture ability through measures of prior academic success and the cost of law school. Added control variables now include indicator variables for 24 categories of undergraduate school quality, undergraduate GPA (indicators for 3.75-4, 3.5-3.74, etc.), a full set of interactions between these undergraduate quality and GPA variables, an indicator variable for being in the top $10 \%$ of her undergraduate class, undergraduate major (indicators for science, business, social science, humanities, and other/missing), whether the person went to a public law school, and an indicator variable for other graduate degrees. The additional control variables make much more of a difference now and, specifically, this is driven by the undergraduate quality measures. As the table shows, lawyers in the top decile of their undergraduate class earn $8 \%$ more, on average, than other lawyers. Looking at the college quality indicators carefully shows that, with all the column 4 controls included, lawyers that went to a Top Undergraduate school (as defined above) earn $20 \%$ more than those that went to other schools. So this regression indicates that Top 10 law school graduates earn about $16 \%$ more than Top 11- 
20 graduates and that lawyers that went to elite undergraduate schools earn an additional $20 \%$ regardless of their law school. Thus, the regression in column 4 leads to two conclusions. First, there is still a substantial premium for going to a top law school, even including all the controls we can. Second, the fact that undergraduate school matters so much means that selection on unobservables is important for lawyers. If all this selection is captured by the undergraduate school categories, then column 4 captures the causal effect of going to a top law school. But that seems unlikely to be an entirely valid assumption and we will use other methods to explore the role of unobservables.

The fifth column performs an analysis similar to the one column 4, using the Wave 2 sample of lawyers (that is, those who had passed the bar seven years before the time of the survey. Column 5 does not include controls for undergraduate GPA (which we do not have for Wave 2) or undergrad GPA/undergraduate school quality interactions, but is otherwise the same as column 4 . The results are quite similar to those for Wave 1 in terms of the magnitude of the law school quality coefficients. Note that the female wage discount is higher, as many women have pulled back on their hours. Also note that the r-square is much lower (by much more than the difference in explanatory variables would justify), which is typical as workers age and pay becomes more a function of individual ability than of observed proxies (Altonji and Pierret (2001).)

Table 5 limits the analysis to lawyers from Top 20 schools in order to focus on a somewhat more homogeneous sample. If the effects of some of the control variables are much different for lawyers that go to lower tier schools than for those that go to top schools, for example, then the restriction imposed in Table 4 (that the control variables have linear and constant effects for the all Top 100 graduates) would limit the ability of these variables to properly control for factors that could affect our school selectivity estimates. This does not appear to be a major concern, however, as the results for the differences between lawyers from Top 10 schools and those ranked 11-20 in Table 5 are almost identical to those in Table 4. Also, comparing the two panels of the table again shows the results are similar for the two different waves of AJD respondents.

Figure 3 graphically represents the relation between income and class rank in law school. Class rank is self-reported, and may be subject to considerable recall bias. ${ }^{10}$ Due to these data problems, we do not use class rank in our formal analysis, but two patterns in the graph are instructive nonetheless. First, pay shows no evidence of declining with law school class rank at Top 10 schools but does drop off appreciably at the other levels. Second, pay at Top 10 schools is higher at all but the highest class ranks (as well as for the large group of Top 10 graduates that did not provide

\footnotetext{
${ }^{10}$ In our sample, $25 \%$ of AJD respondents did not provide a class rank and those who did seem to have been, on average, remembering their law school grades somewhat favorably. $15 \%$ of the AJD sample (and 20\% of those who answered the class rank question) said they were in the top $10 \%$ of their class and $38 \%$ ( $51 \%$ of those who answered the question) said they were in the top quartile.
} 


\begin{tabular}{|c|c|c|c|c|}
\hline \multicolumn{5}{|c|}{ Panel A: Wave 1 AJD Lawyers } \\
\hline & (1) & $(2)$ & (3) & (4) \\
\hline \multirow[t]{2}{*}{ Rank 11-20 } & -0.250 & -0.251 & -0.227 & -0.166 \\
\hline & $(0.048)$ & $(0.048)$ & $(0.049)$ & $(0.058)$ \\
\hline \multirow[t]{2}{*}{ Female } & & -0.182 & -0.192 & -0.209 \\
\hline & & $(0.049)$ & $(0.050)$ & $(0.053)$ \\
\hline \multirow[t]{2}{*}{ Near Mother } & & & -0.080 & -0.078 \\
\hline & & & $(0.052)$ & $(0.055)$ \\
\hline \multirow{2}{*}{\multicolumn{2}{|c|}{ Undergrad Top $10 \%$}} & & & 0.038 \\
\hline & & & & $(0.074)$ \\
\hline R-Square & 0.0553 & 0.0882 & 0.1307 & 0.3696 \\
\hline $\mathrm{N}$ & 471 & 471 & 471 & 471 \\
\hline \multicolumn{5}{|c|}{ Panel B: Wave 2 AJD Lawyers } \\
\hline \multirow[t]{2}{*}{ Rank 11-20 } & -0.233 & -0.219 & -0.200 & -0.171 \\
\hline & $(0.060)$ & $(0.059)$ & $(0.062)$ & $(0.066)$ \\
\hline \multirow[t]{2}{*}{ Female } & & -0.293 & -0.286 & -0.270 \\
\hline & & $(0.060)$ & $(0.061)$ & $(0.063)$ \\
\hline \multirow[t]{2}{*}{ Near Mother } & & & -0.012 & -0.015 \\
\hline & & & $(0.065)$ & $(0.066)$ \\
\hline R-Square & 0.0265 & 0.0884 & 0.1293 & 0.1603 \\
\hline $\mathrm{N}$ & 554 & 554 & 554 & 554 \\
\hline
\end{tabular}

Table 5: Top School Lawyer Pay Regressions. Same analysis as Table 4, except limited to graduates of top 20 law schools. Column 2 includes demographic controls. Column 3 adds family background and school funding controls. Column 4 adds academic history controls. 


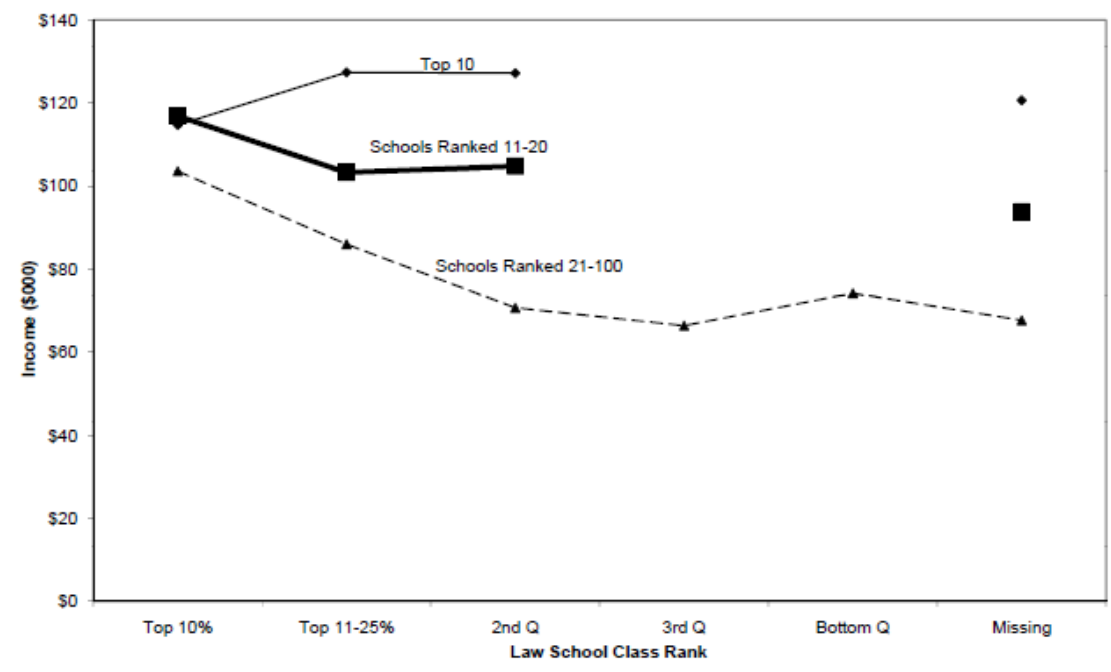

Figure 3: Income by School Quality and Class Rank. Class Rank and income are both self-reported in AJD survey. Wave 1, 2002.

a class rank) than pay at any class rank of any other school. ${ }^{11}$ While certainly not proof of the causal effect of going to a top school, the figure is consistent with the hypothesis that top students at schools outside the Top 10 could expect to earn more if they went to a Top 10 school, even if they were further down in the quality distribution at that school.

For comparison purposes, Appendix Table 3 shows the results of similar regressions on the NLSY cross-section in 1990. To make the sample comparable to our lawyer sample, we include only people with at least two years of college. The results show that college quality does not appear to be an important determinant of pay in this sample. The average person in the highest tier of colleges earns an average of $6 \%$ more than a person in the second tier. But this effect is not statistically significant. The top tier premium grows as college quality drops but the difference only becomes statistically and economically significant when reaching schools with average SAT scores below 840 . When all the controls are included, which makes the NLSY specification comparable to the full set of controls used in column 4 of Table 4 for lawyers, the school quality/income relationship is very small and the controls have a noticeably larger effect on the undergraduate school quality coefficients than they have on the law school quality coefficients.

The regressions so far provide at least circumstantial evidence consistent with law school quality having a larger effect on lawyer income than undergraduate school quality has on income. Further, they suggest that selection is a larger component of the undergraduate selectivity effect than of the

\footnotetext{
${ }^{11}$ The slightly lower pay for top decile students at Top 10 schools is based on a small sample and is not significantly smaller than other Top 10 students.
} 
law school ranking effect. The evidence is consistent with law school quality having a substantial causal effect on lawyer income and a bigger effect than undergraduate quality has on income. However, we did find that undergraduate school quality is related to lawyers' incomes in a way that substantially lowers the implied effect of law school quality.

Our analysis thus far is limited by the fact that the AJD covers only attorneys with seven years or less of experience and by the lack of information about LSATs. ${ }^{12}$ We can partially address these issues by examining data from other sources. We first examine whether the relation (whether causal or not) between law school quality and career success continues as lawyers gain experience beyond the level captured by the AJD second wave. One indication that this relationship is longterm is that lawyers from top law schools are highly over-represented in the partnership of top law firms. The data used in Oyer and Schaefer (2010a) include background information for the partners of 285 of the 300 largest law firms in the U.S. Using this data and data on the number of people that graduated from each U.S. law school, we calculated that, as of the Summer of 2007, $13.4 \%$ of graduates of Top 10 law schools between 1970 and 2005 were partners at one of these 285 firms. $8.9 \%$ of graduates of Top 11-20 schools and 3.5\% of graduates of other Top 100 schools were partners at these firms.

The 1994-1995 Chicago Lawyers Survey provides another dataset we can use to examine how the school-quality/career-success relation changes as lawyers gain experience. This survey of lawyers based in Chicago has some important limitations for our purposes. To the extent that part of the effect of law school quality is sorting lawyers into more productive locations, that will be lost when looking at lawyers in a single location. Also, the survey gathered significant demographic data, but did not ask for undergraduate GPA or major. The survey does include the name of the person's undergraduate school, so we can control for quality of undergraduate school. Using the 848 lawyers in this sample for which we have sufficient data, we ran regressions of log annual pay on the same law school quality variables we used in Table 4. One specification includes no controls, another controls for years since law school graduation (linear and squared), indicators for female, minority, married, mother was/is a professional, father was/is a professional, either parent was/is a lawyer, grew up in Chicago, and grew up in Illinois, while the third controls for all those variables plus indicators for undergraduate school average SAT score (in 100 point increments). The results of all these specifications are similar (though somewhat less precisely estimated) to those in Table 4. The Top 10 premium relative to Top 11-20 is approximately $20 \%$.

We used another dataset, The University of Michigan Law School Alumni Survey, to try to more

\footnotetext{
${ }^{12}$ Note that, while the creators of the AJD have a measure of LSAT success, they have chosen not to make this variable available to insure confidentiality and because they do not believe it is reliable for inference in this sample.
} 
directly assess the importance of not being able to control for LSAT scores. ${ }^{13}$ This comes at the rather steep cost of taking away our variable of interest, as there is no variation in law school quality among this group. We used data from surveys done five years after graduation for the classes of 1991-2000 and ran regressions of log annual pay (which is measured four years after graduation) on undergraduate GPA, LSAT percentile, fraction of law school paid for by family and savings, and indicators for female, minority, married, each graduating class, 5-year age groupings, whether the person lives in the same state as his/her parents, parent occupations (lawyer, professional, business owner), non-law graduate school, four undergraduate major categories, University of Michigan undergraduate degree, and Ivy League/Seven Sisters undergraduate degree. Within this one school, very little of the variation in wages can be explained - even with all these controls, the r-square of the regression is only 0.0677 . The noteworthy finding for our purposes is that LSAT score is not significantly related to pay in this regression. Also, whether LSAT score, undergraduate school, and undergraduate GPA are included or not has no effect on the other variables in the regression. Of course, whether including these variables would have an effect on a school quality measure is not known and it seems plausible that, to the extent LSAT scores predict earnings, they do so across rather than within law schools. However, these results provide at least a bit of evidence that LSAT scores do not explain lawyer pay accurately and to the exclusion of other variables.

\subsection{Job Quality Probits}

It seems unlikely that any given employer of lawyers would vary pay for new lawyers based on where they went to school, so we expect the return to selective law schools to operate largely by sorting lawyers from more selective schools into higher paying firms. We now look for evidence of this sorting by analyzing the relationship between law school prestige and the propensity of lawyers to work in the highest-paying segment of the law sector. Private law firms are the highest paying jobs, on average, for new lawyers, with compensation considerably greater than pay in the public sector, as in-house counsel, or other jobs law graduates take. ${ }^{14}$ Opportunity to work on the most interesting and lucrative work is generally considered to be greatest in the largest legal markets (see Garicano and Hubbard (2009)), so we focus on the four largest legal markets - New York, Washington, Los Angeles, and Chicago.

\footnotetext{
${ }^{13}$ For details on the data and examples of other studies that use it, see Lempert, Chambers, and Adams (2000) and Sauer (1998).

${ }^{14}$ UCLA law school's website provides relevant statistics for its 2007 graduates. The median starting salary for lawyers at firms with at least 250 lawyers was $\$ 160,000$ and dropped monotonically with the size of the firm. Pay at public sector or private sector jobs outside law firms was considerably less, on average.
} 


\begin{tabular}{lcccc}
\hline & $(1)$ & $(2)$ & $(3)$ & $(4)$ \\
\hline Rank 11-20 & -0.101 & -0.100 & -0.092 & -0.052 \\
& $(0.019)$ & $(0.019)$ & $(0.019)$ & $(0.021)$ \\
Rank 21-100 & -0.331 & -0.325 & -0.320 & -0.226 \\
& $(0.031)$ & $(0.031)$ & $(0.032)$ & $(0.036)$ \\
Female & & 0.003 & 0.003 & 0.002 \\
& & $(0.019)$ & $(0.019)$ & $(0.018)$ \\
Near Mother & & & -0.034 & -0.026 \\
& & & $(0.019)$ & $(0.018)$ \\
Undergrad Top 10\% & & & & 0.010 \\
& & & & $(0.029)$ \\
Controls & no & yes & yes & yes \\
Demographic & no & no & yes & yes \\
Family Background & no & no & yes & yes \\
School Funding & no & no & no & yes \\
Academic History & & & & \\
& 0.108 & 0.114 & 0.139 & 0.231 \\
Pseudo R-Square & 1,531 & 1,531 & 1,531 & 1,531 \\
N & & & & \\
\hline
\end{tabular}

Table 6: Lawyer Placement at Top Firms. Each column is a probit where the dependent variable equals one if the person works for a 100+ lawyer firm in one of the top four law markets (NYC, DC, LA, or Chicago.) The dependent variable equals one for $18.2 \%$ of the sample. Displayed coefficients are marginal effects of a one unit change in the explanatory variable. Sample is the same as the wage regressions above, though a few lawyers are included here that did not provide wage information.

Table 6 contains the results of probit regressions where the dependent variable equals one if the AJD respondent works at a private law firm with at least 100 lawyers in one of the four largest legal markets. Note that all our analysis in this section is limited to Wave 1 of the AJD because we do not know where the Wave 2 lawyers live. The coefficients in the table are the marginal effect of a one unit change in the explanatory variable, so the coefficient of -0.101 on "Rank 11-20" in column 1 means that graduates of Top 11-20 schools are 10 percentage points less likely to hold one of these top jobs than a Top 10 graduate when we do not include any controls. That is a very large difference, given that approximately $18 \%$ of the AJD sample works in one of these top jobs.

Moving to the right of the table and adding controls, we find that about a half of the top job/top school relationship can be explained with controls for pre-law-school academic history. Top 10 graduates have a 5.2 percentage point advantage in these sought-after jobs when we add our full set of controls. The effects of the control variables in Table 6 on the effect of going to a top school mirrors that of the control variables in Table 4 which supports the hypothesis that the effect of 
school selectivity on earnings comes through sorting lawyers into higher paying firms. ${ }^{15}$

\subsection{Heterogeneity of Effects}

In order to generate further insight into the sources of the law school prestige effects we have measured so far and the degree to which they may be driven by unobserved variables, we now measure the degree to which these effects vary across various subsamples of the AJD sample. For simplicity, we limit the sample to graduates of Top 20 law schools and we compare Top 10 graduates to other Top 20 graduates.

Table 7 presents the results, with Wave 1 wage regressions in Panel A, Wave 2 wage regressions in Panel B, and Wave 1 job quality probits in Panel C. Columns 1 and 2 perform the analyses in column 4 of Tables 5 and Table 6 separately for women and men. All panels show that the point estimates for law school prestige effects are higher for men than for women and that the effect of prestige is not significant for women. However, the gender effects are also not significantly different from one another or from the coefficients for the sample as a whole shown in earlier tables. The point estimates suggest that the larger effects of undergraduate school quality for men than for women (see Black and Smith (2004) and Hoekstra (2009)) may apply for law school quality, as well. ${ }^{16}$ But the sample size is not large enough to say this confidently.

Columns 3 and 4 split the sample based on whether a lawyer lives near his/her mother and is representative of several analyses we did splitting the sample based on background characteristics. In Panels A and B, we find that there is no significant difference between the financial rewards to going to a top law school for these groups. In Panel C, we do not have an estimate of the effect of going to a top school on getting a top job for lawyers that live near their mothers because, once all the controls are added, so many observations drop out of the probit that the estimate is meaningless. But column 4 shows that the effect for the sample that lives far from their mother is similar to the effect overall. Based on the results in columns 3 and 4, as well as other similar analyses, we do not find noteworthy differences in subsamples split by these characteristics.

Columns 5 and 6 show that law school prestige is much less closely related to labor market success for graduates of top undergraduate schools than for other lawyers. The estimates for Top Undergraduate lawyers (as defined above) in column 5 provide no evidence at all of a link between law school prestige and labor market success. Going to a Top 10 law school does not appear to

\footnotetext{
${ }^{15}$ In unreported probits, we find similar effects if the dependent variable equals one for lawyers working at $100+$ lawyer firms in any geographic market.

${ }^{16}$ Arcidiacono, Cooley, and Hussey (2008) also find that school quality has a smaller effect on female wages than male wages for their MBA sample in their preferred specifications.
} 


\begin{tabular}{|c|c|c|c|c|c|c|}
\hline \multicolumn{7}{|c|}{ Panel A: Wage Regressions, Wave 1} \\
\hline & \multicolumn{2}{|c|}{ Gender } & \multicolumn{2}{|c|}{ Live Near Mother } & \multicolumn{2}{|c|}{ Undergraduate } \\
\hline & & & Within & More than & Top & Other \\
\hline & $\begin{array}{c}\text { Women } \\
\text { (1) }\end{array}$ & $\begin{array}{l}\text { Men } \\
(2)\end{array}$ & $\begin{array}{c}50 \text { Miles } \\
(3)\end{array}$ & $\begin{array}{l}50 \text { Miles } \\
\text { (4) }\end{array}$ & $\begin{array}{c}\text { Undergrad } \\
(5)\end{array}$ & $\begin{array}{c}\text { School } \\
\quad(6)\end{array}$ \\
\hline Rank 11-20 & $\begin{array}{c}-0.108 \\
(0.109)\end{array}$ & $\begin{array}{l}-0.183 \\
(0.092)\end{array}$ & $\begin{array}{l}-0.156 \\
(0.128)\end{array}$ & $\begin{array}{l}-0.141 \\
(0.081)\end{array}$ & $\begin{array}{l}-0.041 \\
(0.088)\end{array}$ & $\begin{array}{l}-0.301 \\
(0.089)\end{array}$ \\
\hline R-Square & 0.4499 & 0.5344 & 0.6663 & 0.4138 & 0.2833 & 0.4793 \\
\hline $\mathrm{N}$ & 242 & 229 & 162 & 309 & 199 & 272 \\
\hline
\end{tabular}

\begin{tabular}{lcccccc}
\hline \multicolumn{7}{l}{ Panel B: Wage Regressions, Wave 2 } \\
\hline Rank 11-20 & -0.148 & -0.193 & -0.085 & -0.223 & -0.026 & -0.241 \\
& $(0.124)$ & $(0.075)$ & $(0.137)$ & $(0.082)$ & $(0.099)$ & $(0.096)$ \\
R-Square & 0.1883 & 0.2852 & 0.3119 & 0.2210 & 0.2311 & 0.1618 \\
N & 257 & 297 & 180 & 374 & 230 & 324
\end{tabular}

\begin{tabular}{lcccccc}
\hline \multicolumn{7}{l}{ Panel C: Top Job Probits } \\
\hline Rank 11-20 & -0.001 & -0.142 & n/a & -0.069 & 0.045 & -0.239 \\
& $(0.118)$ & $(0.073)$ & n/a & $(0.085)$ & $(0.095)$ & $(0.094)$ \\
& & & & & & \\
Pseudo R-Square & 0.3125 & 0.3418 & n/a & 0.2308 & 0.2395 & 0.3505 \\
N & 256 & 241 & 169 & 328 & 213 & 284 \\
\hline
\end{tabular}

Table 7: Top School Lawyer Analyses - Heterogeneous Effects. All specifications in Panel A are the same as column 4 of Table 5 with sample limited as indicated. All specifications in Panel B are the same as column 5 of Table 5 with sample limited as indicated. All specifications in Panel $\mathrm{C}$ are the same as column 4 of Table 6 with sample limited as indicated and to only Top 20 law school graduates. 


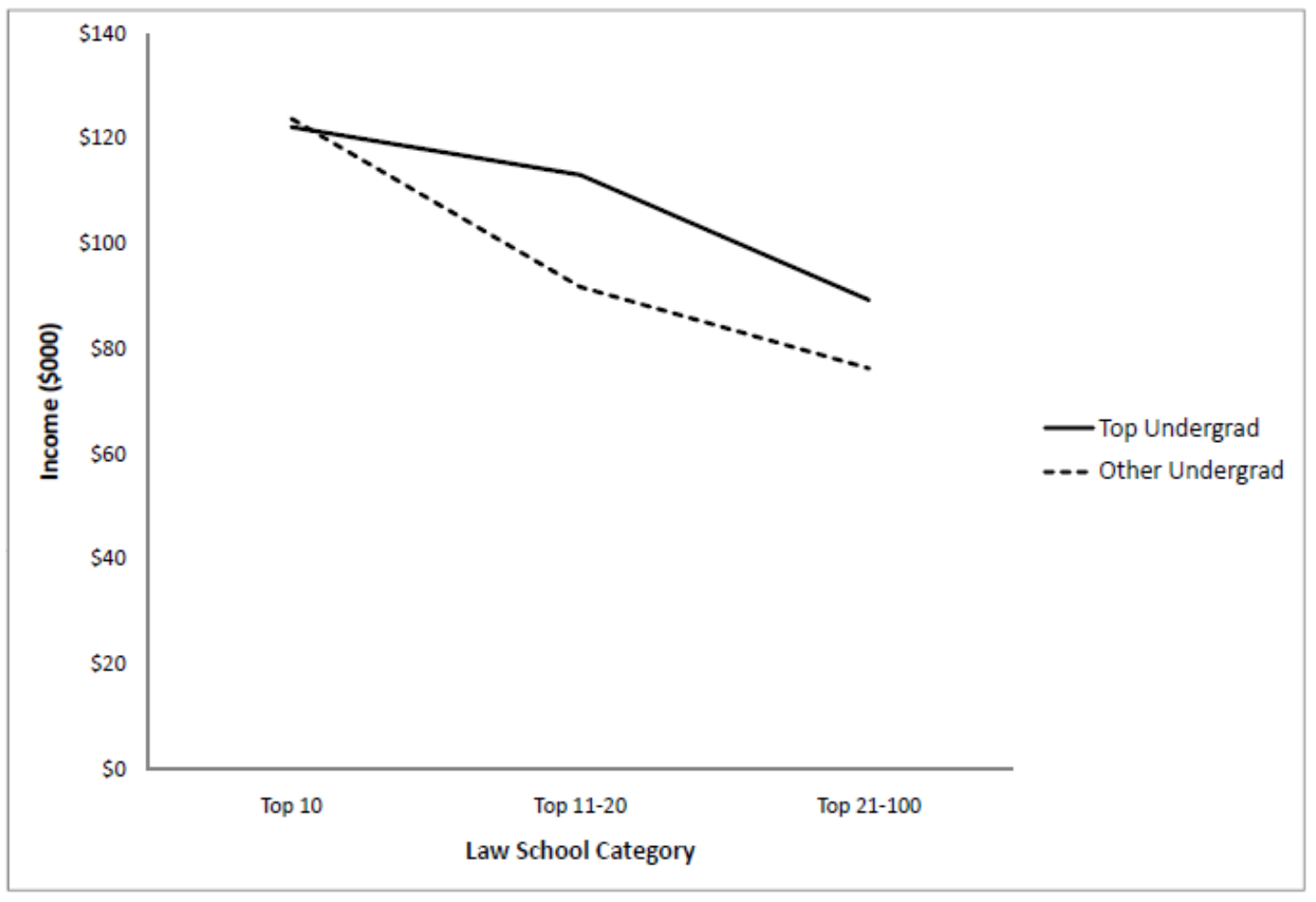

Figure 4: Income by Undergraduate and Law School Quality.

help the initial legal careers of graduates of elite undergraduate schools. Column 6, on the other hand, shows very large effects of going to a top law school for graduates of all other colleges. Using our full set of control variables (including indicators for undergraduate school quality within this sample and interactions of undergraduate quality with undergraduate GPA), we find that graduates of Top 10 schools make approximately 24-30\% more than other Top 20 law school graduates. Top 10 graduates are thirteen percentage points more likely to work at a large firm in a top market.

Figure 4 graphs the relationship between income and the prestige of lawyers' undergraduate and law schools. The graph shows average incomes for lawyers grouped by law school tier and divided into Top Undergraduate school graduates and lawyers that attended other schools. Pay rises steadily with law school quality, with the exception of Top 10 vs. Other Top 20 law schools graduates who attended Top Undergraduate schools. This figure, as well as columns 5 and 6 of Table 7, indicate that lawyers who graduate from an elite law school or an elite undergraduate school earn a substantial premium but that the marginal effect of going to a second elite school is very small. That is, we find no evidence that lawyers who go to Top Undergraduate schools earn a further premium for attending a top law school. 


\section{Using Observables to Assess Selection Bias}

We now follow Altonji, Elder, and Taber (2005) and consider how the relationship between unobservable factors, the schools lawyers attend, and their future careers may affect the interpretation of our results. ${ }^{17}$ It is simplest to do this when looking at two endogenous indicator variables rather than an indicator variable (top school) and a linear variable (pay). Consider the following three equation system:

$$
\begin{gathered}
c=1\left(x^{\prime} \gamma+\eta>0\right), \\
y=1\left(x^{\prime} \beta+\alpha c+\varepsilon>0\right),
\end{gathered}
$$

and

$$
\left[\begin{array}{l}
\eta \\
\varepsilon
\end{array}\right] \sim N\left(\left[\begin{array}{l}
0 \\
0
\end{array}\right],\left[\begin{array}{ll}
1 & \rho \\
\rho & 1
\end{array}\right]\right) .
$$

We use two $y$ indicator variables that capture success at the time of the interview, the indicator for working in a 100+ lawyer firm in a top four market that we analyzed in Table 6 and an indicator variable for having income greater than $\$ 100 \mathrm{~K}$ per year. The results in Table 6 are estimates of equation (4) under the assumption that $\rho=0$. If we had a credible instrument for school quality or were willing to make strong functional form assumptions, we could estimate $\alpha$. As a substitute for that, we now estimate the three equation system above, making various assumptions about the value of $\rho$. We start with $\rho=0$, which is what we have been doing to this point and tells us the value of $\alpha$ if the variables in $x$ fully control for the endogeneity of school quality. Then we use bivariate probits and increase $\rho$ in steps until it is no longer statistically significant and, eventually, changes sign. This tells us how large $\rho$ has to be for selection to fully explain the relationship between school quality and our measures of $y$.

Table 8 presents our results. We limit our results in this sample to the Wave 1 sample, but the results for Wave 2 (which we can do for wages only) are similar to those presented for Wave 1. Columns 1-3 look at the indicator variable for lawyers making over $\$ 100 \mathrm{~K}$ per year for various treatment and control groups. In each case, there is a very large and significant coefficient on going to a top school when running a probit of the pay variable on the school prestige variable with no

\footnotetext{
${ }^{17}$ We know of no other work that uses the methods in Altonji, Elder, and Taber (2005) to study the effects of school quality on labor market outcomes. See Hinrichs (2009) for an analysis of the effect of attending a diverse college which is very similar in spirit to our approach.
} 
controls (the first row) and (as in Table 4) this coefficient drops by about one-third when including all available controls. The coefficients remain strongly positive and statistically significant for $\rho$ 's of up to 0.1. When we assume $\rho$ is 0.2 , the estimated effect of law school prestige becomes small and insignificant when comparing Top 10 schools to schools ranked 11-20 or comparing Top 11-20 schools to Top 21-100 schools. It is very difficult to know what the correlation of the disturbances in equations (3) and (4) might be. We do know that the correlation between the school prestige and pay indicator variables for the sample and groups in column 1 of Panel A of Table 8 is 0.2381 , which means that the correlation of the disturbances with the full set of controls we have available would have to be nearly as great as the correlation of the variables themselves if selection fully explains the school prestige relationship with pay. That is not implausible but also does not strike us as likely.

Column 4 of Panel A shows that the message is quite different when looking at college quality and the NLSY sample. The bivariate probit in that column is limited to NLSY respondents in the two highest college quality groups and the pay indicator variable is defined at roughly the median for this sample. The effect of college prestige is small and insignificant even with no controls and gets noticeably smaller (though not by a statistically significant amount) when we add all the available control variables (that is, controls similar to those we have available for the lawyer sample.) The estimated effect of college quality turns negative at very low levels of $\rho$. While we do not know what level of $\rho$ is reasonable for either sample, Panel A provides further evidence that selection in college prestige is more important than in law school prestige and is consistent with a larger causal effect of law school reputation than undergraduate school reputation. In later drafts, we hope to make further use of the methods in Altonji, Elder, and Taber (2005) and include analyses that will allow us to make informed estimates of $\rho$.

Panel B of Table 8 redoes the analysis in columns 1-3 of Panel A, but using working at a large firm in a top market as the labor market outcome variable. The effect of law school prestige becomes insignificant at a slightly smaller level of $\rho$ for the Top 20 sample in column 1 , but the basic message is similar to that in Panel A. While we do not know what $\rho$ is, there is little reason from these results to make us believe selection dominates the law school prestige effect on job placement.

\section{$5 \quad$ Propensity Score Matching}

We now use propensity score matching as another means of controlling for selection into high prestige schools. Our NLSY analysis is quite similar to that of Black and Smith (2004), though we use slightly different samples and variables and we do not separate our analysis by gender. 


\begin{tabular}{|c|c|c|c|c|}
\hline \multicolumn{5}{|l|}{ Panel A: High Pay } \\
\hline Sample & AJD & AJD & AJD & NLSY \\
\hline Dependent Variable & Pay $>\$ 100 K$ & Pay $>\$ 100 K$ & Pay $>\$ 100 K$ & Pay $>\$ 27.5 \mathrm{~K}$ \\
\hline Treatment & Top 10 & Top 10 & Top 11-20 & Avg SAT > 1120 \\
\hline Comparison & Top $11-20$ & Top 21-100 & Top 21-100 & SAT 1040-1120 \\
\hline \multirow[t]{2}{*}{$\rho=0$, no controls } & 0.629 & 1.170 & 0.541 & 0.101 \\
\hline & $(0.118)$ & $(0.101)$ & $(0.085)$ & $(0.131)$ \\
\hline \multirow[t]{2}{*}{$\rho=0$, full controls } & 0.481 & 1.019 & 0.466 & 0.038 \\
\hline & $(0.139)$ & $(0.121)$ & $(0.089)$ & $(0.158)$ \\
\hline \multirow[t]{2}{*}{$\rho=0.1$} & 0.314 & 0.853 & 0.292 & -0.128 \\
\hline & $(0.138)$ & $(0.121)$ & $(0.088)$ & $(0.157)$ \\
\hline \multirow[t]{2}{*}{$\rho=0.2$} & 0.144 & 0.682 & 0.117 & -0.294 \\
\hline & $(0.137)$ & $(0.120)$ & $(0.088)$ & $(0.156)$ \\
\hline \multirow{2}{*}{$\rho=0.3$} & -0.028 & 0.504 & -0.060 & -0.459 \\
\hline & $(0.135)$ & $(0.118)$ & $(0.086)$ & $(0.153)$ \\
\hline \multicolumn{5}{|c|}{ Panel B: Work at 100+ Lawyer Firm in Top 4 Market } \\
\hline \multirow{2}{*}{$\begin{array}{l}\text { Treatment } \\
\text { Comparison }\end{array}$} & Top 10 & Top 10 & Top 11-20 & \\
\hline & Top 11-20 & Top 21-100 & Top 21-100 & \\
\hline \multirow[t]{2}{*}{$\rho=0$, no controls } & 0.517 & 1.184 & 0.667 & \\
\hline & $(0.118)$ & $(0.102)$ & $(0.097)$ & \\
\hline \multirow[t]{2}{*}{$\rho=0$, full controls } & 0.356 & 1.075 & 0.591 & \\
\hline & $(0.136)$ & $(0.120)$ & $(0.105)$ & \\
\hline \multirow[t]{2}{*}{$\rho=0.1$} & 0.188 & 0.901 & 0.418 & \\
\hline & $(0.136)$ & $(0.130)$ & $(0.104)$ & \\
\hline \multirow[t]{2}{*}{$\rho=0.2$} & 0.019 & 0.723 & 0.244 & \\
\hline & $(0.134)$ & $(0.128)$ & $(0.103)$ & \\
\hline \multirow[t]{2}{*}{$\rho=0.3$} & -0.152 & 0.539 & 0.070 & \\
\hline & $(0.132)$ & $(0.126)$ & $(0.101)$ & \\
\hline
\end{tabular}

Table 8: Sensitivity Analysis: Estimates of School Quality Effects Given Various Estimates About Correlation of Errors. Each entry is the coefficient in a bivariate probit regression of the treatment variable on a high pay indicator (Panel A) or an indicator for holding a job in NYC, LA, DC, or Chicago at a firm with 100 or more lawyers, where the correlation between the error terms in the two probits within the bivariate probit are assumed to equal the value of rho listed. Sample in each analysis is limited to the treatment and comparison groups. Control variables in all but the first row of each panel include age (five-year indicators), fraction of law school paid for by savings and family, and indicator variables for minority, female, married, living within 50 miles of lawyer's mother, mother born outside U.S., one of parents is a lawyer, public law school, in top 10GPA was 3.75 or higher, and undergraduate major was humanities or missing. 


\begin{tabular}{lll}
\hline \multicolumn{2}{l}{ Panel A: AJD } & \\
& Wave 1 & Wave 2 \\
\cline { 2 - 3 } Rank 11-20 & -0.018 & -0.094 \\
& $(0.077)$ & $(0.097)$ \\
Rank 21-100 & -0.276 & -0.221 \\
& $(0.094)$ & $(0.090)$ \\
\hline
\end{tabular}

Table 9: Propensity Score Matching Results. Matches lawyers from Top 10 schools with lawyers from each of the other categories in separate analyses. The sample and specification is similar to column 4 of Table 4, except some covariates had to be dropped to insure convergence.

Our lawyer analysis is similar in spirit to Black and Smith (2004), but the sample and variables are completely different. This allows us to interpret our propensity score matching results for lawyers relative to college students and to use the importance of selection in college choice as a benchmark. Black and Smith (2004) provide a very useful and intuitive discussion of the benefits and drawbacks of using propensity score matching in this context (see section 5 of their paper.) Basically, we observe a "treated" population, which is those who went to Top 10 law schools, and an "untreated" population, which is those who went to lower ranked schools. We Top 11-20 and Top 21-100 schools separately relative to Top 10 schools.

As we have shown above, and especially in Table 3, assignment of $c$ is not random and it is difficult to estimate the treatment effect of going to a top school, which, in the notation of equations (3) and (4), can be expressed as $E\left(y_{c=1}-y_{c=0} \mid c=1\right)$. Our prior regressions measured $E\left(y_{c=1}-y_{c=0} \mid x\right)$, leaving open the possibility that some unobservable factors not captured by $x$ affects both $c$ and $y$. By matching each person for whom $c=1$ to a person with very similar $x$, we can relax the assumption in our previous regressions that linear controls for $x$ eliminate selection bias. However, matching requires that $\operatorname{Pr}(c=1 \mid X)<1$ for all $x$ - that is, for any given $x$, there must be some person that does not go to a top tier law school. Whereas in the regression context, we wanted to add as many controls as possible to the $x$ vector to minimize selection bias, matching people based on a larger set of $x$ variables can lead to what is commonly known as the "curse of dimensionality." That is, if conditioning on enough $x$ variables leads to a set of people that all attended top schools, there will be nobody in the untreated group with whom these people can be matched. As a result, in some of our comparisons between top tier schools and other tiers, we have to drop some covariates and hope that these are not the key variables that drive both school selectivity and ability. We reduce the most important selection covariates (undergraduate school quality) to a single indicator variable for Top Undergraduate school (as defined previously.)

We implement matching using the nearest neighbor method and the Stata programs described in 
Becker and Ichino (2002). ${ }^{18}$ Table 9 shows that our propensity score matching estimate of the Top 10 premium relative to Top 11-20 schools casts considerable doubt on the causal effect of going to an elite law school. The effect is small and insignificantly different from zero. However, the matching estimates are somewhat imprecise so that estimated Top 10 premium is also insignificantly different from the coefficient in column 4 of Table 4 . These matching results add further concern about the importance of selection, but continue to leave open the possibility of a substantial causal effect of going to a top law school.

Appendix Table 4 presents propensity score matching estimates of the returns to college quality measures for the NLSY sample. That exercise serves two purposes. First, it shows that propensity score matching and OLS lead to similar conclusions in the undergraduate context. Our results are consistent with the findings of Black and Smith (2004), at least for men and they provide further confirmation that undergraduate college prestige has relatively little effect on earnings. Second, we do the propensity score matching with and without two "intelligence" measures, AFQT and SAT scores, to the NLSY matching analysis. The addition of these intelligence measures has only a trivial effect on the coefficients, suggesting that the lack of direct intelligence measures may not be driving our results for law schools.

\section{Interpretation}

\subsection{Reconciling the Results}

Our results so far have established the following:

- Graduates of Top 10 law schools earn about a 25\% premium relative to graduates of other Top 20 law schools. Very little of this premium can be explained by the reasonably extensive controls for demographics, background, school funding sources, and pre-law graduate degrees.

- The premium for going to a top law school drops substantially (and, using some methods, becomes negligible) to a degree that is consistent with the law school premium being largely driven by selection of high ability aspiring lawyers by high prestige schools.

- When looking at lawyers that went to the most elite undergraduate institutions, there is little evidence of a premium for going to a top law school.

\footnotetext{
${ }^{18}$ We have performed similar analyses using alternative matching methods (radius matching, multiple neighbors, and kernel matching) and using the Stata matching commands developed by Leuven and Sianesi (2003). Some of our results are sensitive to these choices, but the results we present are consistent with the majority of alternative specifications we considered.
} 
- The premium for going to a top law school is much higher, and remains very high despite extensive controls, for graduates of less elite undergraduate institutions.

- Lawyers that went to elite undergraduate schools earn a substantial premium relative to other lawyers, even controlling for quality of law school and other characteristics. This premium is substantially larger than most estimates of the returns to undergraduate school prestige for broader (that is, non-lawyer) samples.

We believe this set of results is consistent with any or all of the following three explanations:

Top Schools Teach and Prepare Lawyers Better: One possibility is that the top law schools actually produce, on average, more value added for their students - or at least that they produce more value for those students that did not go to elite undergraduate instititions. If top schools really add much more value, it must be the case that the quality of education drops very steeply as one drops down the law school distribution. Given the effects are much smaller for elite undergraduate lawyers, it could be the case that top schools at either level provide some set of skills that is critical to excelling as a lawyer (perhaps analytical thinking and/or writing skills) that most lawyers cannot get without attaining at least one elite degree. While it is hard to imagine that there could be such a difference in the teaching at Top 10 and other Top 20 schools, perhaps the effects of being surrounded by the most capable peers at elite undergraduate or law schools is what sets the learning at these institutions apart.

School-Based Networks: While the previous explanation involved elite schools differentiating themselves from other schools through their teaching, perhaps the top school effects we have documented are driven by the networks lawyers develop in school. If lawyers that go to elite schools learn more from their relatively talented peers while in school and develop social connections with their classmates that are valuable in the labor market, then we would see graduates of more prestigious schools making more money. Suppose that, in a very simplistic depiction of the lawyer market, there are only two networks - a high-level network where the most talented workers do the most difficult and lucrative legal work and the low-level network where other lawyers work and transact. Further suppose that, regardless of innate ability, a lawyer that goes to either an elite law school or an elite undergraduate school is more likely to be admitted to the high-level network than any other lawyer but that there is no marginal return, in terms of admission to the high-level network, from going to elite undergraduate and law schools. That is, suppose a lawyer that goes to the University of Utah for both undergraduate and law degrees is less likely than a lawyer that went to Stanford for undergraduate or law school to be able to join the high-level network and that a lawyer that went to Stanford for undergraduate school and Harvard for law school is no more likely 
to be in the network than a lawyer that got one degree at Stanford and one at University of Utah. This would explain the pattern we showed in Figure 4. It is also consistent with analyses we have done elsewhere using a sample of lawyers at the largest and most prestigious firms. In Oyer and Schaefer (2010a), we show that law school is an important factor determining which lawyers match with each other at these firms We show evidence consistent with networks within these schools (that is, preferences for lawyers from the same school to work together to capture either productivity or non-pecuniary benefits) driving this matching. In Oyer and Schaefer (2010b), we show that lawyers are less likely to leave their firms if there are lawyers with whom they share common schools (law school or undergraduate school) in their office. The evidence we have presented here is broadly consistent with this idea of elite-school-based networks being an important driver of the school prestige relationship to law labor market outcomes.

Unobservables: Though we have done a great deal to control for as much as we can, we simply cannot rule out that highly talented potential lawyers have some innate skill that is observable to admissions officers of top undergraduate schools and top law schools, but not to us. This could be information provided in the form of letters of reference or essays, for example, that indicates work ethic or some other important skill that is not evident from grades and test scores. If these skills are particular valuable for lawyers, then one could imagine that talented prospective lawyers would be admitted to elite schools but would have done almost as well had they attended less elite schools. While we hope that our crudes uses of propensity score matching and looking at the potential effects of unobservables make this somewhat less likely, we hope to refine our use of the methods in Altonji, Elder, and Taber (2005) in future drafts.

On the other hand, we do not think the set of results in this paper can be reconciled with the following models and we therefore do not think they are likely to be important determinants of wages in the market for lawyers.

Information Limitations: We do not think that the large association between law school reputation and labor market success results from an information problem on the part of employers that hire lawyers. If, even with such information as grades and honors, firms cannot easily distinguish the ability of law students, they might rely on the reputation of law and undergraduate schools as the primary signal of the applicant's ability. Going to (and, since we control for undergraduate grades, doing well at) an elite school at either level could be a sufficient signal of high ability to impress top firms. But this idea would suggest that high ability lawyers from lower ranked law schools would catch up with lawyers from higher ranked schools as their careers develop. In that case, we would expect the top school premium to dissipate over time. Given that all our results are similar for the Wave 1 and Wave 2 sample, we think this is unlikely. 
Law School Admissions Preference for Less Prestigious Schools: If undergraduate school is a variable where law schools and their admissions offices value diversity, then we might expect that law schools provide the equivalent of affirmative action on behalf of students from less prestigious undergraduate schools. That is, top law schools may fear that, if they admit strictly by test scores and similar factors, they would fill their class with Ivy League (and equivalent) undergraduates. As a result, all else equal, an applicant to a top law school who received his undergraduate degree at the University of Utah may be more appealing to the admissions committee than an undergraduate from Stanford. If this is the case, then we would expect that graduates of top undergraduate schools would be of higher ability, holding quality of law school constant. This would explain the large measured return to attending an elite undergraduate school in our sample. However, this idea does not seem to fit with the pattern in Figure 4. The graph shows that pay is lower for graduates of less prestigious undergraduate schools that go to every tier of law school below the Top 10 but that Top 10 graduates make the same regardless of the prestige of their undergraduate institution. So there is no evidence that Top 10 students from less prestigious undergraduate schools are less skilled than Top 10 lawyers from elite undergraduate schools, which suggests law firm admissions preference cannot fully explain our results.

Lawyer Preferences Correlated with School Quality: One idea that may help explain how selection effects are related to lawyer pay and school prestige is that lawyers that are more ambitious apply to more prestigious schools. So lawyers that go to a top law school or a top undergraduate school are simply the ones that are most ambitious and, therefore, most successful. This would lead to a large return to attending either a top undergraduate or law school and not (necessarily) a marginal return to attending both. However, while this could also be a contributing factor to our results, we would also expect the background characteristics to be more related to the law school prestige premium. For example, if preferences and ambition drove the selection into top law schools, we would expect the law school premium to be smaller when controlling for how close a lawyer lives to his/her family and how they paid for law schools. But, as we showed earlier, controlling for these variables has no effect on the law school premium.

\subsection{Investments by Aspiring Lawyers}

While we have not drawn as definitive a conclusion as we would have liked about the financial returns to attending a selective law school, we now perform simple thought experiments to determine the implications for law school applicants of the possible interpretations of our results. Consider a law school applicant that, with probability one, can get into a law school ranked approximately 
fiftieth. ${ }^{19}$ She would like to attend Stanford Law School (the representative top 10 school for this analysis) if at all possible and, if not, she prefers UCLA (our representative school ranked in the second ten) to the options ranked around fiftieth.

To formulate estimates of the probability that a student will get into Stanford and UCLA, we use self-reported admissions outcomes from lawschoolnumbers.com of people that applied for Fall 2008 entry to law school. We cannot be sure that people report reliably, but the website is anonymous so there is little incentive to misreport. More problematically, we have no idea whether there is selection bias as to who participates in this voluntary website and whether people that report outcomes here are more or less likely than others to get in. So these admissions probabilities should be thought of as having wide standard errors. We approximate admissions probabilities for individual schools within 5-point LSAT ranges.

Suppose our hypothetical aspiring lawyer received a score of 163 on the LSAT. One out of a total of 25 people with LSAT scores between 160 and 164 report being admitted to Stanford so we assume our lawyer has a $4 \%$ probability of getting into Stanford. Five out of 65 UCLA applicants with LSAT scores in this range report being admitted, so she has a $7.6 \%$ chance of being admitted there. Assume maximum admissions correlation (that is, all applicants that are admitted to Stanford are also admitted to UCLA). If our lawyer does nothing to increase her LSAT score, she will go to Stanford with $4 \%$ probability, UCLA with $3.6 \%$ probability, and the school ranked around fiftieth with $92.4 \%$ probability.

Our estimates of her expected income are based on a survey of Stanford Law School alumni that was conducted in 2007 and included just over 1,000 alumni from the classes of 1987-2006. These respondents were asked, "What is your total annual income, before taxes, from your CURRENT job? Please include salary, bonuses, profit sharing, and any other direct financial compensation." They were asked to check a box for no income, under $\$ 50 \mathrm{~K}, \$ 50 \mathrm{~K}-\$ 99 \mathrm{~K}, \$ 100 \mathrm{~K}-\$ 199 \mathrm{~K}, \$ 200 \mathrm{~K}-\$ 399 \mathrm{~K}$, $\$ 400 \mathrm{~K}-\$ 599 \mathrm{~K}, \$ 600 \mathrm{~K}-\$ 2$ million, or over $\$ 2$ million. We assign the midpoint of each category and $\$ 3$ million for those earning over $\$ 2$ million. There were 790 valid responses. We took the average income by graduating class and, after discounting by zero (this would assume that discounting will be exactly outweighed by the increase in earnings for lawyers with a given number of years of experience in the time between graduation and when the person reaches that level of seniority), $5 \%$, or $10 \%$, added these up as an estimate of what an aspiring lawyer attending Stanford could expect to earn over the first twenty years after graduation. These averages are $\$ 6$ million for zero discounting, $\$ 3.5$ million when discounting by $5 \%$, and $\$ 2.25$ million when applying a $10 \%$ discount

\footnotetext{
${ }^{19}$ Southern Methodist University is ranked fiftieth in the US News 2003 rankings, just below Tulane University and the Universities of Alabama, Maryland, and Washington.
} 


\begin{tabular}{lcccc}
\hline & LSAT $=163$ & LSAT $=168$ & LSAT = 173 & Relative Wage \\
\cline { 2 - 5 } Prob(attend) Stanford & $4.0 \%$ & $14.5 \%$ & $19.0 \%$ & $100 \%$ \\
Prob(attend) UCLA & $3.6 \%$ & $60.5 \%$ & $73.0 \%$ & $85.4 \%$ \\
Prob(attend) \#50 School & $92.4 \%$ & $25.0 \%$ & $8.0 \% \%$ & $71.8 \%$ \\
& & & & \\
Exp. Income, No Discount & $\$ 4.41 \mathrm{~mm}$ & $\$ 5.05 \mathrm{~mm}$ & $\$ 5.22 \mathrm{~mm}$ & \\
Exp. Income, 5\% Discount & $\$ 2.57 \mathrm{~mm}$ & $\$ 2.94 \mathrm{~mm}$ & $\$ 3.05 \mathrm{~mm}$ & \\
Exp. Income, 10\% Discount & $\$ 1.65 \mathrm{~mm}$ & $\$ 1.89 \mathrm{~mm}$ & $\$ 1.96 \mathrm{~mm}$ & \\
\hline
\end{tabular}

Table 10: Estimates of Relationship Between LSAT Scores and Income. Probabilities of attending each school based on self-reported admission outcomes for applicants to UCLA and Stanford for entry in Fall of 2008 on lawschoolnumbers.com. Potential assumed to be able to get into 50th ranked school with certainty. "Relative Wage" is based on column 4 of Table 4 . Expected income over first twenty years after graduation for Stanford graduates based on averages from survey of Stanford classes of 1987-2006.

rate. We assume that these are our lawyer's expected earnings if she goes to Stanford.

We start by estimating the largest law school premium we believe to be at all plausible by assuming that the controls in column 4 of Table 4 fully capture all relevant observable and unobservable characteristics. Under this assumption, the lawyer's earnings would be $84.9 \%$ of the Stanford earnings if she goes to UCLA (which is based on the -0.158 coefficient in Column 4 of Table 4), and that her earnings are $71.5 \%$ of the Stanford level if she goes to a school ranked fiftieth (based on the -0.331 in Column 4 of Table 4).

Column 1 of Table 10 shows that, given these assumptions, our lawyer's expected income with her LSAT of 163 is approximately $\$ 4.4$ million if she does not discount future income streams, $\$ 2.6$ million if she discounts at $5 \%$, and $\$ 1.6$ million if she discounts at $10 \%{ }^{20}$ Column 2 shows that our lawyer's chances of getting into a Top 10 or Top 20 school and, therefore, her income are enhanced significantly if she can increase her LSAT scores by 5 points. If she does not discount, five LSAT points are worth about $\$ 600,000$ in expectation and $\$ 200,000$ if she discounts by the full $10 \%$. The increases are smaller (nearly $\$ 200,000$ without discounting and $\$ 70,000$ with $10 \%$ discounting) for a further increase in LSAT scores from 168 to 173. Even taking our lowest estimates and allowing for some noise in our estimates, these estimates suggest that such actions as LSAT preparation classes, spending time refining admissions essays, and even studying hard in relevant undergraduate classes in hopes of improving grades all have a significant positive return for aspiring lawyers if our regressions fully control for unobservables.

Another thought experiment is to consider an aspiring lawyer trying to maximize her income

\footnotetext{
${ }^{20}$ We believe that $10 \%$ is probably too large a discount factor given the age/wage gradient for lawyers in the Stanford survey suggests that real wages would be dropping for most of the twenty years we measure.
} 
who has been admitted to Stanford and UCLA. Assuming room and board costs would be roughly the same at each school (they could be lower outside Silicon Valley and Los Angeles, but not by enough to affect this decision), the key difference is tuition. Stanford tuition costs $\$ 40,000$ for a total of about $\$ 120,000$ over the time in law school, while UCLA's tuition is $\$ 81,000$ tuition $(\$ 27,000$ per year for three years). The total difference is $\$ 39,000$, which is about $1-2 \%$ of the discounted expected income over the first 20 years of the lawyer's career. This suggests that, as long as the causal portion is at least one eight of the measured $16 \%$ premium for going to Stanford instead of UCLA, the lawyer is better off paying to go to the more prestigious school. If she were offered a scholarship such that she paid no tuition to go to UCLA, the marginal cost of going to Stanford $(\$ 120,000)$ would be as much as about $6 \%$ of her expected future income. For a lawyer facing this choice, making the right decision requires taking a stand on the degree to which she thinks unobservables contribute to the $16 \%$ premium in Table 4 . We hope that further refinement of our analysis, as well as the analysis we will do of the AJD's second wave, will pro is at least one . What does the causal effect of going to a top school have to be to justify the extra expense? Assuming room and board costs would be roughly the same at each school (they could be lower outside Silicon Valley and Los Angeles, but not by enough to affect this decision), the key difference is tuition. Stanford tuition costs $\$ 40,000$ for a total of about $\$ 120,000$ over the time in law school.

Is there ever an argument to be had for attending UCLA or the lower ranked school? Without discounting, the premium for Stanford relative to UCLA totals over $\$ 1$ million and, relative to the lower-ranked school, is nearly $\$ 2$ million. At $10 \%$ discounting, these figures drop to approximately $\$ 400 \mathrm{~K}$ and $\$ 750 \mathrm{~K}$, respectively. Assuming room and board costs would be roughly the same at each school (they could be lower outside Silicon Valley and Los Angeles, but not by enough to affect this decision), the key difference is tuition. Stanford tuition costs $\$ 40,000$ for a total of about $\$ 120,000$ over the time in law school. Even if UCLA or a lower ranked school offered a full tuition scholarship, the aspiring lawyer would be better off in terms of expected wealth by attending Stanford. If she did not get into Stanford, it would also be worth paying UCLA's $\$ 81,000$ tuition $(\$ 27,000$ per year for three years) instead of taking free tuition at a lower-ranked school.

\section{Conclusions}

We used a representative sample of lawyers that first passed the bar in 2000 to show that, as of 2002 and 2007, there was a large wage premium associated with having gone to a highly ranked law school. Lawyers from Top 10 schools made about $25 \%$ more than those from the next ten schools and much more than those from schools ranked further below. Lawyers from top schools were also 
considerably more likely to hold jobs at large firms in top legal markets. Adding controls for various demographic factors that might affect both where a lawyer went to school and her later success did surprisingly little to lower the strong effect of going to a top law school. However, controlling for the quality of a lawyer's undergraduate school made a significant difference in our estimates and suggested that unobservables are an important issue. As a result, we are left with evidence that there may be a substantial causal effect of going to a top school, but this conclusion depends on the assumptions one is willing to make about the role of unobservables.

We hope that refining our analysis of the relationship between observables and unobservables (see Section 4 above), we make some headway on understanding the degree to which our estimates are still plagued by selection. But we also feel that the current results are informative in ruling out various models that one might suspect drive the wages of lawyers. 


\section{References}

Altonji, J. G., T. E. Elder, and C. R. Taber (2005): "Selection on Observed and Unobserved Variables: Assessing the Effectiveness of Catholic Schools," Journal of Political Economy, 113, 151-184.

Altonji, J. G., And C. R. Pierret (2001): "Employer Learning and Statistical Discrimination," Quarterly Journal of Economics, 116, 313-350.

Arcidiacono, P., J. Cooley, And A. Hussey (2008): "The Economic Returns to an MBA," International Economic Review, 49, 873-899.

Becker, S., And A. Ichino (2002): "Estimation of Average Treatment Effects Based on Propensity Scores," The Stata Journal, 2, 358-377.

Behrman, J. R., M. R. Rosenzweig, and P. Taubman (1996): "College Choice and Wages: Estimates Using Data on Female Twins," Review of Economics and Statistics, 78, 672-685.

Black, D. A., And J. A. Smith (2004): "How Robust is the Evidence on the Effects of College Quality? Evidence from Matching," Journal of Econometrics, 121, 99-124.

Brewer, D., E. Eide, and R. Ehrenberg (1999): "Does it Pay to Attend an Elite Private College? Cross Cohot Evidence on the Effects of College Type on Earnings," Journal of Human Resources, 34, $104-123$.

Dale, S. B., And A. B. Krueger (2002): "Estimating the Payoff to Attending a More Selective College: An Application of Selection on Observables and Unobservables," Quarterly Journal of Economics, 117, $1491-1527$.

Ehrenberg, R. G. (1989): "An Economic Analysis of the Market for Law School Students," Journal of Legal Education, 39, 627-654.

Galanter, M., And T. Palay (1991): Tournament of Lawyers: The Transformation of the Big Law Firms. University of Chicago Press, Chicago.

Galanter, M. S., and W. D. Henderson (2008): "The Elastic Tournament: A Second Transformation of the Big Law Firm," Stanford Law Review, 60, 1867-1929.

Garicano, L., and T. N. Hubbard (2009): "Specialization, Firms, and Markets: The Division of Labor Within and Between Law Firms," Journal of Law, Economics and Organization, 25, 339-371.

Henderson, W. D., And A. P. Morriss (2006): "Student Quality as Measures by LSAT Scores: Migration Patterns in the U.S. News Rankings Era," Indiana Law Review, 81, 163-204.

Hinrichs, P. (2009): "The Effect of Attending a Diverse College," Georgetown University Working Paper.

Hoekstra, M. (2009): "The Effect of Attending the Flagship State University on Earnings: A Discontinuity-Based Approach," Review of Economics and Statistics, 91, 717-724. 
Lempert, R. O., D. L. Chambers, and T. K. Adams (2000): "Michigan?s Minority Graduates in Practice: The River Runs Through Law School," Law and Social Inquiry, 25, 395-505.

Leuven, E., And B. Sianesi (2003): "PSMATCH2: Stata module to perform full Mahalanobis and propensity score matching, common support graphing, and covariate imbalance testing," available at http://en.scientificcommons.org/988304.

Oyer, P., And S. Schaefer (2010a): "Firm/Employee Matching: An Industry Study of American Lawyers," Stanford University and University of Utah.

(2010b): "Personnel Economics: Hiring and Incentives," Stanford University and University of Utah.

Rosen, S. (1992): "The Market for Lawyers," Journal of Law and Economics, 35, 215-246.

SaAvedra, J. (2008): "The Returns to College Quality: A Regression Discontinuity Analysis," Harvard University Working Paper.

Sander, R. H. (2004): "A Systematic Analysis of Affirmative Action in American Law Schools," Stanford Law Review, 57, 367-483.

Sander, R. H., And E. D. Williams (1989): "Why Are There So Many Lawyers? Perspectives on a Turbulent Market," Law and Social Inquiry, 14, 431-479.

SAuer, R. (1998): "Job Mobility and the Market for Lawyers," Journal of Political Economy, 106, 147-171.

SpurR, S. J. (1987): "How the Market Solves an Assignment Problem: The Matching of Lawyers with Legal Claims," Journal of Labor Economics, 5, 502-532.

Wightman, L. F. (1990): "Self-reported Methods of Test Prepartion Used by LSAT Takers," Research Report 90-01, Law School Admission Council. 


\section{Appendix: Undergraduate School Quality}

We analyzed the relationship between undergraduate college quality and earnings after college using two different datasets. We present detailed results in this appendix using data from the National Longitudinal Survey of Youth (NLSY). This is a panel survey of over 12,000 people that were between the ages of 14 and 21 when the survey began in 1979. To make our analysis comparable to the AJD survey, in terms of the age of the population, we use a cross-section of respondents in 1990 (though many of the background variables are gathered from earlier survey years.) Because our goal is to look at the effect of college quality measures, we limit the sample to people that have completed at least two years of college, those that report the college they attended, and those who provided compensation data in 1990. We divided the colleges attended into quintiles such that the top and second group are similar proportions of the NLSY sample as the Top 10 and Top 20 groups are of the AJD sample. We define the Top Tier of colleges as those where the average combined SAT score (according to US News and World Report, as of 1991) is above 1120 and the second tier includes schools with an average SAT score above 1040 and not greater than $1120 .^{21}$

Panel B of Table 2 displays summary information for the sample we use in our wage regressions below and for those portions of the sample that went to the highest and second highest school tiers. As with the AJD sample, the NLSY sample is about half male and averages about thirty years of age (though the age variation is smaller because NLSY ages only vary by up to six years whereas our AJD sample includes people between 25 and 39.) As with the lawyers, the NLSY respondents at better schools come from families with more education and they are more likely to live somewhere different from where they grew up. Again, those going to better schools both make more after school and show more skill before school (as measured by SAT scores), so it is not entirely clear whether the school quality/wage correlation is due to selection or a causal effect of school quality on earnings. The rest of the tables in this appendix are meant to parallel tables in our AJD analysis and are discussed briefly in the text.

Black and Smith (2004) use the same data, though they use the 1998 cross-section. They point out that, when trying to identify the causal effect of school reputation on income, it is somewhat debatable whether to include years of schooling as an explanatory variable. People that go to better schools are more likely to complete more education. So, if one of the ways going to a better

\footnotetext{
${ }^{21}$ Schools just making the cutoff into the top group include American University, Saint Olaf College, and UCLA. Those with average SATs just above 1040, and therefore making the second tier cutoff, include University of Central Florida, University of San Diego, and Evergreen State College in Washington. Our results are similar when we use other measures of school quality, such as freshman retention rate or expenditure per student, or an average of several measures. Also, note that our definition of an elite undergraduate school is quite different (and much less exclusive) when looking at the NLSY sample than when looking at the AJD sample.
} 
school increases earnings is by increasing completed education, controlling for education will lead to understating the effect of school quality on pay. We therefore think estimates without years of education would be the best indication of the effect of college quality on earnings and would leave it out of our regressions if this were our primary goal. However, we are only using the NLSY for the purposes of comparing the effect of undergraduate school prestige to law school prestige. Given that the lawyers in our sample are homogeneous in terms of their education level, we include years of education in our NLSY regression so that, in both samples, we are measuring the effect of school quality independent of its effect on how much schooling the person gets. ${ }^{22}$ Similarly, tenure on their current job is very homogeneous for the AJD sample but quite variable for the NLSY sample, so we control for months of tenure on the current job throughout the analysis below. Also note that the female coefficient in our NLSY regressions indicates a very large gender gap because we use annual earnings and women work fewer hours, on average. When we look at hourly wage, the female coefficient is cut dramatically (to about -0.12.)

The second dataset we used to study undergraduate school quality is the Baccaleureate and Beyond (B\&B) survey. This survey, which focuses on people that received undergraduate degrees in 1992-1993, has some advantages relative to the NLSY. The total sample size is similar to the NLSY, but the focus on college graduates makes the relevant sample size for our purposes much larger. We can therefore look at finer levels of college quality and, in particular, focus on undergraduates that are more similar to our lawyer sample. However, the B\&B's cost relative to the NLSY is that it has less background, demographic, and high school data. As a result, we could not include as many of the controls that are the key to our attempts to separate selection effects from value added by more selective schools. We did all the analysis we do with the NLSY using B\&B incomes in the 2003 follow-up survey. We defined school quality the way we define it in the NLSY and we also did it using higher average SAT cut-offs for the highest quality school groups. We found that the college quality effects are quite similar to those in the NLSY and they respond similarly to the demographic controls we do have in the B\&B. Overall, our conclusions are very similar whether we use the B\&B or the NLSY for our undergraduate analysis. Details of our B\&B analysis are available on request, but we do not present them here.

\footnotetext{
${ }^{22}$ The coefficient on years of education is approximately 0.08 for the regressions we run, though it drops to about 0.063 when we control for test scores.
} 


\begin{tabular}{lccc}
\hline & All & Top Tier College & 2nd Tier College \\
\hline Female & 0.518 & 0.500 & 0.436 \\
Age & 29.609 & 29.440 & 29.173 \\
& $(2.266)$ & $(2.310)$ & $(2.284)$ \\
Financial Aid & 0.534 & 0.546 & 0.495 \\
Mother's Education & 12.696 & 14.030 & 12.771 \\
& $(2.896)$ & $(2.978)$ & $(2.354)$ \\
Moved since age 14 & 0.664 & 0.728 & 0.728 \\
SAT \%ile & 0.576 & 0.803 & 0.652 \\
Years of Education & $(0.271)$ & $(0.208)$ & $(0.223)$ \\
& 16.149 & 16.917 & 16.329 \\
Annual Pay & $(1.365)$ & $(1.445)$ & $(1.274)$ \\
& $\$ 25.8 \mathrm{~K}$ & $\$ 29.6 \mathrm{~K}$ & $\$ 26.9 \mathrm{~K}$ \\
$\mathrm{~N}$ & $(13.2 \mathrm{~K})$ & $(16.2 \mathrm{~K})$ & $(12.3 \mathrm{~K})$ \\
\hline
\end{tabular}

Appendix Table 1: Summary Statistics, NLSY Sample interviewed in 1990 


\begin{tabular}{lccc}
\hline & Top Tier Logit & Top Tier Logit & OLS: Tier \\
\hline Female & 0.003 & 0.080 & 0.006 \\
& $(0.012)$ & $(0.052)$ & $(0.016)$ \\
Minority & 0.000 & 0.119 & 0.001 \\
& $(0.015)$ & $(0.070)$ & $(0.013)$ \\
Mother's Education & 0.007 & 0.026 & 0.008 \\
& $(0.002)$ & $(0.008)$ & $(0.002)$ \\
Top 10\% of HS Class & 0.053 & 0.118 & 0.071 \\
& $(0.020)$ & $(0.065)$ & $(0.019)$ \\
SAT \%ile & 0.050 & 0.142 & 0.047 \\
& $(0.008)$ & $(0.038)$ & $(0.008)$ \\
N & 1,767 & 381 & 1,767 \\
\hline
\end{tabular}

Appendix Table 2: Undergraduate Selection into Top Schools

Selection into Top Undergraduate schools. Sample is from 1990 NLSY interviews of people with two or more years of college education. Columns 1 and 2 are probits where the dependent variable is an indicator variable for graduating from a school where the average SAT score is above 1120. The sample in column 2 is limited to those who went to schools with average SAT scores above 1040. Column 3 shows results from an OLS regression where the dependent variable is 1 if the person went to a school with average SAT scores above 1120, 2 if he/she went to a school with average SATs between 1041 and 1120, 3 if he/she went to a school with average SATs between 841 and 1040, 4 if he/she went to a school with average SATs between 771 and 840, and 5 if he/she went to a school with average SATs of 770 or below. Coefficients displayed in logits are marginal effect of a one unit change in the explanatory variable. 


\begin{tabular}{|c|c|c|c|c|c|}
\hline & (1) & $(2)$ & $(3)$ & $(4)$ & $(5)$ \\
\hline SAT 1041-1120 & $\begin{array}{c}-0.061 \\
(0.079)\end{array}$ & $\begin{array}{c}-0.087 \\
(0.078)\end{array}$ & $\begin{array}{c}-0.072 \\
(0.078)\end{array}$ & $\begin{array}{l}-0.052 \\
(0.079)\end{array}$ & $\begin{array}{l}-0.032 \\
(0.079)\end{array}$ \\
\hline SAT $841-1040$ & $\begin{array}{l}-0.113 \\
(0.067)\end{array}$ & $\begin{array}{l}-0.095 \\
(0.065)\end{array}$ & $\begin{array}{l}-0.068 \\
(0.066)\end{array}$ & $\begin{array}{l}-0.047 \\
(0.068)\end{array}$ & $\begin{array}{c}-0.011 \\
(0.069)\end{array}$ \\
\hline SAT 771-840 & $\begin{array}{l}-0.240 \\
(0.075)\end{array}$ & $\begin{array}{l}-0.217 \\
(0.073)\end{array}$ & $\begin{array}{l}-0.184 \\
(0.075)\end{array}$ & $\begin{array}{l}-0.160 \\
(0.078)\end{array}$ & $\begin{array}{l}-0.107 \\
(0.080)\end{array}$ \\
\hline $\mathrm{SAT}<=770$ & $\begin{array}{l}-0.214 \\
(0.089)\end{array}$ & $\begin{array}{l}-0.174 \\
(0.089)\end{array}$ & $\begin{array}{c}-0.132 \\
(0.091)\end{array}$ & $\begin{array}{c}-0.108 \\
(0.094)\end{array}$ & $\begin{array}{l}-0.046 \\
(0.095)\end{array}$ \\
\hline Female & & $\begin{array}{l}-0.350 \\
(0.036)\end{array}$ & $\begin{array}{l}-0.347 \\
(0.036)\end{array}$ & $\begin{array}{l}-0.343 \\
(0.037)\end{array}$ & $\begin{array}{l}-0.326 \\
(0.037)\end{array}$ \\
\hline Move since Age 14 & & & $\begin{array}{c}0.046 \\
(0.039)\end{array}$ & $\begin{array}{c}0.052 \\
(0.039)\end{array}$ & $\begin{array}{c}0.050 \\
(0.039)\end{array}$ \\
\hline Financial Aid & & & $\begin{array}{l}-0.041 \\
(0.038)\end{array}$ & $\begin{array}{l}-0.038 \\
(0.039)\end{array}$ & $\begin{array}{l}-0.040 \\
(0.039)\end{array}$ \\
\hline GPA & & & & $\begin{array}{c}0.045 \\
(0.034)\end{array}$ & $\begin{array}{c}0.032 \\
(0.035)\end{array}$ \\
\hline AFQT & & & & & $\begin{array}{c}0.288 \\
(0.114)\end{array}$ \\
\hline \multicolumn{6}{|l|}{ Controls } \\
\hline Education and Tenure & yes & yes & yes & yes & yes \\
\hline Demographic & no & yes & yes & yes & yes \\
\hline Family Background & no & no & yes & yes & yes \\
\hline School Funding & no & no & yes & yes & yes \\
\hline Academic History & no & no & no & yes & yes \\
\hline Intelligence & no & no & no & no & yes \\
\hline R-Square & 0.064 & 0.124 & 0.133 & 0.140 & 0.149 \\
\hline $\mathrm{N}$ & 1,767 & 1,767 & 1,767 & 1,767 & 1,767 \\
\hline
\end{tabular}

Appendix Table 3: NLSY Pay Regressions.

OLS - Dependent Variable is Log of annual pay. Sample is cross-sectional NLSY sample in 1990, when ages are similar to ADJ sample, and is limited to people with at least two years of college. Average SAT scores, based on US News and World Report 1991 rankings. The excluded category is schools with average SAT scores over 1120. "Move since Age 14" is an indicator variable for living in a different count in 1990 than at age 14. "Financial Aid" is an indicator variable for whether received financial aid (not including loans) to help pay for undergraduate school. "GPA" is high school GPA and "AFQT" is percentile rank on the Armed Forces Qualifying Test. All regressions include linear controls for years of education and tenure in current job. 


\begin{tabular}{lcc}
\hline & $(1)$ & $(2)$ \\
\hline SAT 1041-1120 & -0.116 & 0.052 \\
SAT 841-1040 & $(0.172)$ & $(0.177)$ \\
& -0.060 & -0.052 \\
SAT 771-840 & $(0.103)$ & $(0.110)$ \\
& -0.242 & -0.228 \\
SAT $<=770$ & $(0.111)$ & $(0.215)$ \\
& -0.302 & -0.291 \\
Intelligence Measures & No & Yes \\
\hline
\end{tabular}

Appendix Table 4: Propensity Score Matching Results for NLSY sample.

Matches NLSY respondents that attend top ranked colleges with those from each of the other categories in separate analyses. The sample and specification is similar to column 5 of the previous table, with covariates dropped to insure convergence. 